\title{
BEBIDA, ROÇA, CACCA E AS VARIAÇÕES DO SOCIAL ENTRE OS ARARA DE RONDÔNIA
}

\author{
JÚLIA OTERO DOS SANTOS ${ }^{1}$
}

$U F P A$

\begin{abstract}
RESUMO: Este trabalho detém-se sobre as formas com que os Arara, falantes de uma língua Tupi-Ramarama e habitantes da região do Rio Machado, exibem sua socialidade para si mesmos. Por meio da produção e consumo de na'mẽk kap (bebida doce ou fermentada), da divisão e compartilhamento da caça e das formas de posse e produtividade de suas roças, as pessoas e coletivos fazem e desfazem as mais variadas escalas do social: uma pessoa, uma família, um grupo doméstico, uma aldeia ou um povo. As relações sociais ativadas para a produção elou consumo de bebida, caça e roça criam "espaços-tempos" particulares (MUNN, 1992), caracterizados pelos Arara ora como uma forma social determinada pelo parentesco, ora pela alteridade. Assim, tomar bebida doce ou azeda, cozinhar e compartilhar uma presa inteira ou em pedaços, e fazer uma roça individual ou coletiva são distinções que apontam para um contraste entre estar separado ou estar junto, nos termos araras - entre uma vida entre si e uma vida entre outros, conforme proposto por Lima (2005).
\end{abstract}

PALAVRAS-CHAVE: Arara de Rondônia; bebida; roça; caça; socialidade; espaço-tempo.

ABSTRACT: This work addresses the ways in which the Arara, speakers of a Tupi-Ramarama language and inhabitants of the region around the Machado River, conceive of their sociality. By way of the production and consumption of na'mẽk (a traditional beverage), the division and sharing of hunted game, and the possession and productivity of their swiddens, people and groups of people create and undo social relationships on different scales: the individual, the family, the household, the village and the people. The social relations called upon for the production and/or consumption of drink, game and garden products create particular "spacetimes" (MUNN, 1985) that are perceived on the one hand as social constructs determined through kinship, and on the other determined through otherness. As such, drinking fermented or unfermented na'mẽk, cooking and sharing a whole animal or only portions, or making an individual or a collective swidden are distinctions that, in their own terms, point to a contrast between a life among themselves and a life among others, as proposed by Lima (2005).

KEYWORDS: Arara de Rondônia; beverage; garden; game; sociality; space-time.

\footnotetext{
${ }^{1}$ Doutora em Antropologia Social pela Universidade de Brasília (UnB). Professora de antropologia da Faculdade de Ciências Sociais da Universidade Federal do Pará. Membro do Grupo de Estudos sobre Populações Indígenas (GEPI) e do Laboratório de Antropologias da T/terra da UnB. E-mail: juliaoterosantos@gmail.com.
} 


\section{Estar junto ou estar separado}

O intuito principal deste artigo $^{2}$ é apresentar os modos como os Arara - falantes de ramarama, uma língua isolada do tronco Tupi e habitantes da Terra Indígena Igarapé Lourdes, situada no município de Ji-Paraná, em Rondônia - exibem sua socialidade para si mesmos. É por meio das formulações acerca da caça, das roças e da bebida que as pessoas costumam descrever as relações e formações sociais possíveis de se elicitar. Nas duas aldeias em que realizei a pesquisa, Paygap e Iterap, as pessoas demonstravam uma grande preocupação em torno de assuntos que envolviam essas materialidades, na medida em que é por meio delas que se pode delinear duas formas sociais, entendidas nos termos de um estar separado/individual/por família ou de um estar junto, expressões usadas em português.

Esta é uma oposição contextual e contrastiva, ou seja, os referentes dependem do ponto de vista dos sujeitos e da escala do social tomada como referência para a comparação (se uma maloca, uma família nuclear, um grupo doméstico, uma aldeia ou um povo), mas que remete sempre à diferenciação entre uma socialidade considerada mais restrita, isto é, marcada pelo parentesco e semelhança, e uma mais expandida, marcada pela alteridade e a diferença. Entre uma vida entre si e uma vida entre outros, conforme elaborado por Tânia Stolze Lima (2005) em sua etnografia sobre o povo Yudjá.

Para a autora, grupos que se concebem como um "entre si" de parentes podem assumir diferentes facetas: um povo, uma aldeia, um grupo doméstico, uma família ou um pessoal. Cada uma dessas unidades de caráter fractal são identificações, algo arbitrárias, secionadas e tratadas como ponto de referência em um certo campo relacional. Sua estabilização depende da apropriação por um homem de

\footnotetext{
${ }^{2}$ Esse artigo é baseado em dois capítulos da minha tese, Sobre mulheres brabas, parentes inconstantes $e$ a vida entre outros: a Festa do Jacaré entre os Arara de Rondônia, defendida em janeiro de 2015. A pesquisa foi realizada entre 2010 e início de 2013, em diferentes etapas, perfazendo um total de doze meses de campo. Para realizá-la, contei com apoio da Fundação Ford, por meio do projeto Effects of intellectual and cultural rights protection on traditional people and traditional knowledge. Case studies in Brazil, coordenado por Manuela Carneiro da Cunha, a quem agradeço por ter financiado boa parte da pesquisa de campo. Também agradeço ao Programa de Capacitação Institucional (MPEG/MCTI) pela concessão de bolsa que possibilitou a redação deste artigo.
} 
uma função-Eu definida como uma distribuição diferencial da posição de Sujeito ou presença de uma função de caráter eminentemente político, que, a depender da unidade que destacamos, apresenta diferentes coeficientes de cristalização. Configurações de tipo "entre si" costumam ser engendradas por formas de função-Eu mais cristalizadas. No caso yudjá elas diriam respeito a um "povo-e-seu-capitão" e ao "dono da aldeia" (ou chefe). Uma terceira forma, iwa (dono) ${ }^{3}$, dependente do oferecimento de cauim, seria a menos cristalizada e a que mais facilmente circularia entre os homens, diferentemente das formas capitão ou chefe. Estas, mais cristalizadas,

operam separações (uma família ao lado de outras, um grupo doméstico próprio, uma aldeia separada, um povo à parte, a humanidade de Senã'ã), ao passo que a circulação do iwa torna possível a sogros e genros, pais e filhos, cunhados de mesmo sexo, cunhados de sexo oposto, primos cruzados (imana), enfim, homens e mulheres que se entretenham no mesmo círculo em meio uns aos outros (LIMA, 2005, p. 116).

Oferecer uma caracterização da vida social arara que leve em conta essa variação na constituição das unidades etnográficas com as quais nós, antropólogas, costumamos trabalhar é uma das intenções deste artigo. O caminho percorrido difere, contudo, daquele tomado por Lima. Interessa-me aqui menos a qualidade de "sujeito" da socialidade a função-Eu eminentemente política - do que as coisas ${ }^{4}$ - bebida, presa abatida e roça - que possibilitam que as pessoas distingam diferentes formas de se relacionar: uma concebida enquanto aberta à alteridade (estar junto) e outra caracterizada por se restringir a um círculo de parentes (estar separado).

Todos aqueles com quem ego come junto e compartilha carne e bebida são ditos seus wat tap ( $1^{\text {a }} \mathrm{P}$ - "parentes"), "meus parentes". Wat tap é uma categoria puramente relacional de significado contextual cujo referente mais restrito é um homem, uma mulher e seus filhos, e o mais amplo, um povo. Nos contextos da política indigenista, pode abarcar

\footnotetext{
${ }^{3}$ Iwa é glosado como "dono" pelos Yudjá, mas também se refere a algo pelo qual se tem predileção.

${ }^{4}$ Adoto o termo "coisas" no sentido empregado por Henare, Holdbraad e Wastell (2007), isto é, enquanto uma palavra teoricamente não marcada, mas aberta à experiência etnográfica e possível condutora da produção de conceitos sobre outros mundos.
} 
todos os povos indígenas em oposição aos $p e g^{5}$, brancos. Tap é uma partícula associativa que, segundo Gabas Jr., "tem a função de categorizar um conjunto de entidades associadas com um referente particular como pertencendo a um grupo temporário" (GABAS JR., 1999, p. 67). É usada para "referir-se a uma multiplicidade de diferentes entidades de algum modo relacionadas ao substantivo com o qual elas ocorrem" (p. 68). A partícula agrupa referentes necessariamente distintos uns dos outros. Os Arara traduzem wat tap por "meus parentes". A expressão também pode significar "minhas coisas". Outro uso possível de tap é após um nome próprio em expressões empregadas para se referir ao grupo familiar de determinada pessoa. Fulano tap, "o pessoal de fulano". Essa expressão é particularmente usada com relação aos chefes de família.

Aqueles que, em determinados contextos, não são wat tap de ego são considerados tap páy ("parentes outros", "pessoal outro"). Outra forma possível de se referir a uma alteridade é món tap, traduzida pelo termo genérico "outros". Embora eu não saiba precisar o uso dessa expressão, parece-me que ela aponta para uma alteridade genérica fora do parentesco.

A relação de parentesco é determinada a partir de atos específicos. Restringindo-nos ao assunto que nos interessa aqui, doar ou compartilhar carne, dividir uma roça e compartir bebida são ações que, quando reiteradas ao longo do tempo, aparentam as pessoas. Esses atos compõem uma história que elas podem reafirmar ou esquecer6. Bebida (na'mẽk kap ou simplesmente na'mẽk), presa (makúy, "caça" ou xïm, "carne") e roça (naxey) podem ser resultado da produção doméstica ou coletiva. É para essa distinção, bem como para o compartilhamento, troca e distribuição desses produtos, que as categorias junto e separado apontam nos contextos descritos mais adiante. As diversas ações envolvidas na produção e consumo da caça, roça e bebida podem ser entendidas como atos, no sentido de causarem

\footnotetext{
${ }^{5}$ Alusão ao som produzido pelas armas de fogo usadas pelos não índios. A ocorrência de ideofones onomatopeias com significados verbais muito específicos e que dependem da criatividade dos falantes - é uma marca da língua falada pelos Arara (cf. GABAS JR., 1999).

${ }^{6}$ Sobre a importância da repetição continuada dos atos de cuidado e alimentação para o reconhecimento dos laços de parentesco - no caso entre mães e filhos (no vocabulário tupinambá, de criação ou legítimos) -, ver Viegas (2003).
} 
efeitos, conforme proposto por Munn (1992). Em seu estudo sobre práticas cotidianas e rituais em Gawa, pequena ilha da Melanésia envolvida no circuito do kula, a autora busca determinar as "relações internas" que "dão forma significativa aos atos e que especificam a natureza do valor produzido [...] por meio da análise dos significados culturais implicados nessas práticas" (MUNN, 1992, p. 6). Partindo da ideia da autora de que os processos e princípios socioculturais estão encorporados [embodied] nas formas culturais, que ganham significância por meio da relacionalidade, busco mostrar como bebida, caça e roça aparecem enquanto ícones das relações ativadas pelas pessoas por meio dessas coisas, possibilitando-lhes descrever seus modos de se relacionar.

É preciso esclarecer que a relação dessas formas culturais com a caracterização de duas socialidades distintas emergiu enquanto foco de atenção da pesquisa na medida em que nas duas aldeias meus anfitriões mostravam-se constantemente interpelados por uma questão que poderia ser expressa nos seguintes termos: como criar formas de coletivização para além das famílias e grupos domésticos, estas as "unidades sociais" mais relevantes na vida cotidiana? Os Arara avaliam que, no presente, a promoção de contextos de sociabilidade interfamiliar é algo que se faz com dificuldades: as pessoas preferem viver separadas ao invés de juntas.

A socialidade cotidiana parece ter sempre gravitado em torno do grupo doméstico. Porém, a julgar pela nostalgia das pessoas, e com exceção do período em que viveram nos seringais, as ocasiões para os encontros entre diferentes grupos eram menos raras ou, ao menos, mais desejadas. Elas incluíam festas, visitas entre parentes e trabalho coletivo nas roças. Estes contextos envolvem uma sociabilidade muito valorizada, mas, do ponto de vista arara, raramente engendrada no presente. Fala-se dela nos termos de um estar junto, em oposição a um estar separado ou individual.

Para entender os dispositivos de atribuição de valor e significado às formas de se relacionar, a teoria etnográfica de Munn mostra-se profícua na medida em que elabora um arcabouço teórico capaz de descrever e analisar como a atribuição e a transformação do valor transcorrem. Destaco o conceito de espaço-tempo intersubjetivo ou 
sociocultural, entendido pela autora como uma forma de se mensurar a experiência da viabilidade da vida em comunidade, uma questão que mobilizava parte considerável de meus interlocutores. Para Munn, certos tipos de ação transformativa possibilitam que os habitantes de Gawa criem o valor tido como essencial para tornar a vida em comunidade possível. Ações capazes de promover este valor são caracterizadas pela antropóloga enquanto modos de criação de valor positivo, como as trocas entre parceiros do kula. Esses modos são examinados por Munn em sua relação a modos antitéticos, ou seja, aqueles que minam ou impedem a realização desse valor bem como da construção ideal do self e das relações sociais, como os atos de bruxaria. Desta forma, a comunidade produz a si mesma por meio de um processo dialético. $O$ valor de um ato, seja dar comida a determinados outros ou abrir uma roça, gera efeitos positivos ou negativos, os quais podem ser expressos segundo um parâmetro. Em Gawa, o parâmetro do valor

pode ser caracterizado em termos de níveis diferenciais de transformação espaço-temporal - mais especificamente em termos da capacidade relativa de um ato expandir [...] o espaço-tempo intersubjetivo um espaço-tempo de relações entre o eu e o outro constituído por meio das e nas práticas e atos (MUNN, 1992, p. 9).

No caso das transformações positivas, o espaço-tempo apresenta-se mais estendido, isto é, as relações espaço-temporais vão além do eu. Já uma contração do espaço-tempo é resultado de transformações negativas. A significação do valor se dá por meio de qualidades específicas que caracterizam alguns componentes da prática, tais como o corpo, conchas kula, fama. Estas qualidades são ícones, na medida em que exibem nelas mesmas o valor transformativo de atos e modos de espaço-tempo. Assim como o conceito de ícone, a noção de quali-signo é recuperada por Munn da filosofia de Peirce para referir-se a "certas qualidades encorporadas [embodied] que são componentes de um dado espaço-tempo intersubjetivo (o 'todo mais compreensivo') cujo valor positivo ou negativo elas significam" (MUNN, 1992, p. 17). Assim, lentidão/velocidade, escuro/claro, pesado/leve são quali-signos chaves em Gawa. Alguns meios, em particular corpo e canoas, exibem 
quali-signos de valor positivo ou negativo gerados pelos atos notadamente, atos de transmissão e consumo de comida. O ícone é, portanto, um quali-signo objetificado.

A teoria de Munn, a meu ver, ajuda a compreender a recorrência da bebida, carne e roça nos enunciados de meus principais interlocutores sobre as transformações experimentadas desde 0 contato, isto é, sobre a prevalência, no presente, de uma socialidade caracterizada pela separação. Por muito tempo, as afirmações que escutava sobre a produção e consumo de na'mẽk, caça e roça me confundiam, na medida em que algumas das qualificações que as pessoas davam a essas coisas não pareciam encontrar correspondência na (minha) realidade. A leitura de Munn ofereceu um entendimento $a$ posteriori da experiência de campo. Fazer dessas coisas ícones que apontam para a qualificação de um espaço-tempo não é, portanto, fruto de uma adesão irrefletida a uma teoria, mas uma tentativa, mediada por conceitos arara, de conceber (sensu HENARE, HOLBRAAD e WASTELL et al., 2007, p. 9-13) um mundo no qual essas entidades não são as mesmas que no mundo euro-americano.

Os quali-signos associados à bebida (doce ou azeda), à presa (inteira ou em pedaços) e à roça (individual ou coletiva/ comunitária) são índices das formas possíveis de se relacionar, se junto ou separado. Não se quer dizer com isso que essas sejam as únicas possibilidades imaginadas pelos Arara, mas que essas parecem ser as mais relevantes no contexto de transformação acelerada no qual eles dizem viver. Esse é o contraste marcado quando a questão de fundo que ecoa é como criar espaços-tempos mais estendidos, que possibilitem a criação de uma comunidade e de um povo.

As pessoas atribuem essa dificuldade para se promover espaçostempos mais ampliados a uma preferência generalizada por uma vida individualizante. Esse pendor para uma vida em separado é associado a um movimento de virar branco, como costumam caracterizar seu modo vida contemporâneo. As ações e procedimentos que evidenciam esse virar são inúmeros: uso de roupas, escolarização, diminuição do tempo dedicado às roças, compra de comida no mercado da cidade, frequente preferência de algumas mães pelo leite de vaca em lugar da na'mẽk na alimentação das crianças, relaxamento no seguimento de regras da 
couvade e alguns (poucos) casamentos com brancos.

O contato mais intenso dos Arara com os peg iniciou-se em meados da década de 1940, por meio do engajamento em diferentes atividades relacionadas à economia seringalista na região do Rio Machado. Sobre o período anterior a esse (des)encontro, os velhos costumam sublinhar duas coisas: que os parentes moravam todos juntos em uma mesma maloca e, principalmente, que andavam muito. As pessoas falam de um tempo antigo, associado às andanças e à vida na maloca, e de um tempo mais recente, quando passaram a viver no meio dos brancos. Esta nova era inicia-se a partir do deslocamento para os seringais e do estabelecimento de vínculos com os patrões. Com a chegada do Serviço de Proteção aos Índios (SPI), em meados da década de 1960, as pessoas passaram a alternar períodos na aldeia e em colocações familiares de extração de seringa, quando começaram a trabalhar por conta própria e não mais para os patrões. Assim, o tempo vivido no meio dos peg convive por algum período com as andanças. As movimentações só vêm a cessar, ou diminuir drasticamente, em meados da década de 1980, quando fundaram Iterap e, posteriormente (por volta de 1992), Paygap. No entender dos meus anfitriões, as transformações que se sucedem desde que se encontram irremediavelmente no meio dos brancos favorecem a formação de espaços-tempos marcados pela separação e semelhança em detrimento daqueles marcados pela mistura e diferença.

Embora não seja possível desenvolver o argumento nesse espaço, é fundamental ressaltar que, durante a realização da pesquisa, moradores de Iterap e Paygap estavam ensaiando diferentes respostas para o problema da coletivização - como denomino essa dificuldade de formação de espaços-tempos mais estendidos. Os primeiros mostravam-se engajados em um recente processo de conversão, e os segundos viviam um momento de proliferação de rituais tidos como tradicionais (como o Wayo 'at Kanã) e de iniciativas de transmissão do conhecimento e da cultura dos antigos (como o Encontro de Pajés).

$\mathrm{O}$ que pude observar é que aqueles que moram em Paygap estão

\footnotetext{
${ }^{7}$ Traduzido como Festa do Jacaré, o mote principal do ritual é o assassínio da espécie jacaretinga por mulheres consideradas brabas, seguido por dança com o animal e seu consumo em forma de caldo por todos os participantes.
} 
determinados a criar pausas no devir branco por meio da celebração de rituais e de outros eventos mediados pelo discurso da cultura. Deste modo, estão (deliberadamente) engajados em um virar índio e na produção de uma forma povo. Já os moradores de Iterap não estão interessados em uma imersão no mundo dos projetos ou em experiências de objetivação da cultura. A forma que escolheram para aparecer enquanto um coletivo mais amplo são os cultos realizados na igreja localizada no terreiro de um dos grupos domésticos, onde cantam, dançam e oram. O foco deles está voltado para o virar branco. A conversão, de um modo geral, é formulada por aqueles que a experimentam como uma "negação" da cultura. As práticas valorizadas pelo discurso do resgate cultural, como rituais e xamanismo, são em geral demonizadas e colocadas em suspensão pelos crentes $^{8}$.

\section{Beber na'mẽk kap pe'wit. trocar palavras e fazer parentes}

Em Iterap, segundo dados de 2011 da Fundação Nacional de Saúde (Funasa), vivem cerca de 230 pessoas distribuídas em seções residenciais distantes entre cinco e quarenta minutos de caminhada umas das outras. Cada seção é composta por várias casas que contêm, cada uma, uma família nuclear que compartilha com as demais um terreiro, às vezes uma cozinha (wirik kanã tit, "lugar de cozinhar") 9 e, quando não uma roça, o trabalho para a derrubada, queima e plantio. Em geral, estes núcleos são formados por um casal mais idoso, seus filhos e filhas solteiros, filhos casados com suas esposas e, mais raramente, filhas casadas com seus maridos, configurando uma família extensa (de inflexão virilocal) distribuída em várias casas contíguas.

Denomino esses conjuntos plurifamiliares de grupos domésticos, uma vez que as relações de produção e consumo costumam se dar com maior intensidade entre pessoas que vivem em um mesmo núcleo. Tais grupos emergem nas interações e práticas cotidianas, como nos casos

\footnotetext{
${ }^{8}$ Minha tese de doutorado (OTERO DOS SANTOS, 2015) tem como tema principal o Wayo 'at Kanã, entendido enquanto um espaço-tempo altamente propício ao estabelecimento da dinâmica do junto, de ativação de uma forma povo e de interrupção do devir-branco. Um artigo sobre o assunto encontra-se em elaboração.

${ }^{9}$ Local fora da residência, que pode ser uma construção de palha ou de madeira, geralmente de tábuas velhas reaproveitadas de casas derrubadas.
} 
de compartilhamento de comida e bebida doce, visitas entre casas, saídas para a roça, pescarias e empréstimos de objetos. Por grupo doméstico entendo, portanto, um conjunto de parentes que levanta suas casas próximas umas das outras, ajudando-se mutuamente e compartilhando a comida, a na'mẽk kap pe'wit, um porto, os mesmos caminhos e as palavras.

Em Paygap, uma aldeia menor ${ }^{10}$, composta pela família do cacique Pedro e pelos pais, irmãos e irmãs de Arõy, esposa dele, o esquema de residência em casas compostas por famílias nucleares repete-se. No entanto, as casas são bem próximas umas das outras. Praticamente metade delas pertence aos descendentes do cacique e a outra metade aos irmãos, irmãs e pais de Arõy.

Tanto em Iterap como em Paygap, é comum deparar-se com a reunião de um pequeno grupo de pessoas, geralmente no pátio de uma casa, tomando na'mẽk kap, bebida feita de cará-roxo (ya'mo), carábranco (mara'â), milho (nãya) ou macaxeira (mani) acrescidos de batatadoce (pe'tik) e conhecida regionalmente como "macaloba". Na'mẽk é sempre feita por uma mulher, às vezes ajudada pelas filhas solteiras, em sua cozinha'1. Assim, a macaloba tem sua dona, koa, aquela que comanda a sua produção e, principalmente, de cuja roça vieram os produtos para o preparo da bebida.

A bebida, que chega a render sessenta litros e dificilmente dura mais de três dias, é consumida pelos membros da casa, que a tomam sempre que têm vontade, e oferecida aos visitantes. A maior parte fica armazenada na ma é bap ${ }^{12}$, na cozinha da produtora. Com a chegada, em 2005, da eletricidade fornecida pelo programa do governo federal Luz para Todos, a maior parte das famílias adquiriu freezers ou geladeiras, passando a guardar parte da bebida sob refrigeração em garrafas PET, chamadas regionalmente de "litro".

Quando se faz macaloba doce é comum receber visitas. Ir à roça

\footnotetext{
${ }^{10}$ Segundo dados da Funasa de 2011, Paygap contava com 89 moradores.

${ }^{11}$ Para uma descrição detalhada da fabricação de bebida, ver Otero dos Santos (2015, pp. 167-73). Na'mẽk kap é uma receita gavião. A bebida considerada arara é feita ralando a macaxeira antes de fervê-la e recebe o nome de marixá (o nome de uma variedade da macaxeira) ou na'mẽk kap xa'yoro (macaloba ralada). É necessário mexer o conteúdo durante todo o processo de cozimento. Ocasionalmente, as mulheres ainda fabricam o marixá, mas a preferência é pela na'mẽk kap, uma variedade mais uniforme e encorpada.

${ }^{12}$ Palavra para "panela grande". No caso, trata-se do tipo de recipiente usado como lixeira pelos brancos.
} 
para tirar macaxeira, cará ou milho com a finalidade de produzir a bebida é quase certeza de que as pessoas de fora da casa aparecerão para degustar esse alimento e conversar. Quando um visitante chega, seja ele parente próximo ou distante, branco ou índio, uma das primeiras coisas que a anfitriã irá dizer é: en na'mẽk kap ya'ti nãn ahyâ?, "você quer macaloba?". Caso não tenha a bebida, ela não irá se demorar em anunciá-lo ao visitante.

No que tange às práticas de bebida no passado, a visita à dona da macaloba era obrigatória. Assim, antigamente, mesmo que não houvesse um convite, a etiqueta prezava uma visita àquela que tivesse fabricado a bebida. Como me contou Arõy, esposa do cacique de Paygap, "quando fazia, cada qual ia chamar a gente. A gente tomava macaloba de casa em casa. Da doce. A gente não aguentava, não, tomar tudo. A gente fazia assim. Hoje em dia o pessoal nem faz. Os mais velhos faziam". Certa vez, após eu ter acompanhado uma amiga em uma ida à roça para tirar macaxeira para a produção de na'mẽk kap e não ter aparecido para degustar sua bebida, ela, assim que me encontrou, queixou-se comigo: "fiquei te esperando para tomar macaloba, já acabou", o que certamente foi interpretado pela mulher como uma desfeita de minha parte.

Em geral, a na'mẽk kap é servida pela produtora ou por uma de suas filhas em canecões (leiteiras) ou panelas de alumínio sem cabo que mais parecem cuias, ou seja, em grande quantidade, se comparado ao oferecimento de outros tipos de bebida, tais como café e sucos, mas em pequena quantidade, quando temos em mente o consumo da bebida azeda, sobre o qual falaremos depois. O protocolo determina que os homens sirvam os homens e as mulheres ofereçam às mulheres, mas este rito costuma ser seguido com maior rigor pelos(as) mais velhos(as). Mesmo eles(as) podem servir pessoas do sexo oposto quando há intimidade entre visitante e anfitriã(o).

Em raras ocasiões, os visitantes se reúnem dentro das residências. A preferência é por consumir a bebida e conversar nos terreiros ou nas cozinhas separadas das casas. O interior da casa é o espaço da família que ali habita, sendo de livre acesso somente para as crianças, as que mais transitam entre diferentes casas e terreiros, em geral em grupos de mesmo sexo. 
Os visitantes podem ser tanto parentes próximos - irmãs que se visitam ou filhas e filhos que visitam seus pais ou o contrário - quanto distantes. Quando uma pessoa aparece na casa de alguém com quem o cognato é distante, ela quase sempre vai até lá para tratar de algum assunto específico, que pode demorar a ser introduzido. Visitar um parente distante sem motivos é costume dos mais velhos, que sentem saudades da época do seringal em que iam visitando as colocações dos amigos e parentes. Um bom anfitrião é aquele que oferece bebida, palavras e carne aos seus convidados. A macaloba, como se pode vislumbrar na fala do ex-cacique de Iterap, é o grau zero da hospitalidade.

Nós somos tudo assim... temos que oferecer alguma coisa pro visitante nosso... se vai na casa da gente tem que oferecer alguma coisa... se não tiver nada eu vou falar pra ele que não tem nada pra gente comer hoje. Aí... ele fica satisfeito a mesma coisa... se tiver só a macaloba está bom assim (ARARA, Firmino Ot Xavã apud DE PAULA, 2008, p. 183).

O compartilhamento de bebida doce nos pátios das famílias enseja entre as pessoas um modo de comunicação específico: a conversa. Troca-se palavras com aqueles com os quais se compartilha na'mẽk pe'wit, esta é a ética imposta pela bebida doce. A associação entre macaloba doce e conversa é criadora de um espaço-tempo positivo e muito valorizado pelos Arara. Estas conversas versam sobre assuntos corriqueiros da vida das pessoas, notícias de parentes e lembranças de acontecimentos recentes. Episódios engraçados que envolvam o aprendizado das crianças, relatos de comportamento animal ou outros acontecimentos que julguem divertidos são especialmente propensos a serem narrados nos encontros em torno da bebida doce. Não foram poucas as vezes em que me sentei nos bancos dispostos pelos terreiros das casas e fui incitada a contar alguma história ou falar de meus parentes. Todas as vezes em que permanecia muito tempo em silêncio, era instada a conversar.

Falar é uma habilidade que indica a humanidade do ente, e conversar (weroya, de wero, "fala, língua", e ya, "ir") é a forma por excelência de interação entre os humanos. Não é à toa que um dos 
índices de que se está diante de um kopât ${ }^{3}$ é ele falar que nem gente. Respondê-lo é ser imediatamente capturado pelo seu ponto de vista, engajando-se, dessa forma, em um devir-outro.

A bebida doce deve ensejar a boa conversa, um encontro cordial entre parentes. Nas festas rituais, a comunicação polida também é desejada, mas na medida em que o espaço-tempo ritual envolve um estar entre outros, ela pode muito facilmente descambar para a fofoca esta, uma hiperconversa, wero pâttem, "falar muito" -, antítese do parentesco. $O$ encontro que se dá nos pátios familiares, ainda que possa colocar pessoas nem tão próximas em contato, é regido pela socialidade do parentesco, comandada pelo compartilhamento de bebida, palavras e comida.

Ainda que a visita faça parte das relações acionadas pela macaloba, assim como acontece com os produtos da caça, da pesca e das roças, a na'mẽk kap pe'wit (macaloba doce) é mais comumente compartilhada entre os membros de uma mesma família. Mesmo sendo um chamariz de visitas e um produto que deve ser ofertado, sua produção atende primeiramente à alimentação da família da dona da bebida, dos moradores de sua casa e, em menor medida, de seu grupo doméstico. Diferentemente do cauim alcóolico, somente em um segundo plano a bebida é para "visitantes". Assim, apesar de outros aparecerem ou serem convidados, o motivador principal para a decisão de se fazer macaloba doce está dentro de casa.

É principalmente porque as crianças pequenas desejam que as mães vão à roça ou à "caça" da bebida nas casas de outras produtoras. É para satisfazer esses mais ávidos consumidores que as mulheres empenham-se na fabricação de na'mẽk. As mães insistem em dizer que as crianças reclamam quando não há macaloba. Assim, entre os Arara, a principal relação que a bebida doce coloca em relevo é entre uma mulher e sua prole. A mediação da relação entre marido e esposa por meio da bebida, comum em vários contextos ameríndios (ver GOW, 1989 e VIEGAS, 2003), é algo menos formulado no caso arara. Certamente, fazer roça, fabricar bebida e caçar são práticas que

\footnotetext{
${ }^{13}$ Traduzido como "bicho", kopât é um espírito que age sob a forma de grandes predadores (como onça, capivara e jacaré) para levar a ximit, alma, da pessoa. É também como se referem àquele responsável pela iniciação de um pajé e que vem auxiliá-lo em suas curas.
} 
efetivam uma série de atos que costumam ser atribuídos a um dos gêneros em um espaço convencional ${ }^{14}$. As ações que se desenrolam nos contextos de produção e consumo dessas coisas são atribuídas de modo distinto ao componente masculino ou feminino do par conjugal, esta a unidade de produção cotidiana. Interessa aqui como os produtos do trabalho de um casal adulto contribuem, em uma escala, para a constituição do parentesco e dos corpos arara e, em outra, de coletivos mais ampliados.

À na'mẽk é atribuído o poder de fazer as crianças crescerem e de impedir que adoeçam. Sua ingestão produz corpos xopûttem, gordos. A gordura não exagerada - enquanto índice de uma corpulência saudável que denota principalmente um corpo bem-nutrido e forte, e se opõe à magreza associada muitas vezes a um estado de doença conforme recoberto pelo sentido do termo xakïn - é desejável não somente para os bebês. O corpo de uma pessoa é, em qualquer fase da vida, uma objetivação do resultado das ações de outros. O corpo xopût de um bebê ou criança atesta os cuidados que seus pais e familiares mais próximos tiveram para alimentá-lo, o jeito amoroso de tratá-lo, bem como um resguardo bem-sucedido.

A bebida doce é vetor de assemelhamento. Por um lado, ela contribui para a fabricação do corpo do bebê de uma forma apropriada e, por outro, enseja a conversa entre parentes - ou visitantes que se comportam como parentes - nos terreiros e cozinhas da aldeia.

\section{Caça e divisão da carne}

Embora as pessoas não formulem desse modo, a principal contrapartida do homem à produção da macaloba é caçar, xïm yegat (procurar carne) ou xïm win (matar carne). Estas são atividades

\footnotetext{
${ }^{14}$ Por espaço convencional arara tenho em mente aquilo que, no processo dialético da simbolização delineado por Wagner (1981), aparece como da ordem do dado. Os regimes sociocosmológicos indígenas tendem a privilegiar um modo de simbolização ou ação que Wagner define como diferenciante, no qual as atividades consideradas como propriamente humanas e os modos tradicionais de agir e se comportar são tomados como inatos. Neste sentido, há uma forma arara de ser homem, de ser mulher, de ser um casal, uma filha, etc. Essas formas encontram-se no campo do dado na medida em que são percebidas como já constituídas e não como produtos da ação humana. O que cabe a esta ação é atualizar essas formas e ao mesmo tempo diferenciar-se quanto ao grau e excelência com que isso é feito.
} 
complementares e intransferíveis ao gênero oposto, que conectam o casal por meio de sua prole, pois os Arara dizem que mulheres fabricam bebida e homens caçam para os seus filhos. Ainda que possa existir uma mulher com habilidade cinegética, as mulheres não podem ser ditas caçadoras, no sentido de jamais serem elas as provedoras de carne de uma unidade familiar. A atividade cinegética é, por definição, masculina. Embora atualmente nem todos os homens cacem, ela é a imagem da masculinidade e mesmo da paternidade: pai é quem caça. Um homem que cria o(s) filho(s) de outro torna-se pai na medida em que caça para os filhos da esposa. Neste sentido, caça e bebida aparecem no discurso arara mais como as contribuições masculina e feminina para o crescimento e cuidado dos filhos do que como produtos oferecidos ao sexo oposto em uma relação matrimonial.

A carne é a parte principal de uma refeição. Homens casados que não podem caçar, seja por serem assalariados e precisarem dedicar parte do seu tempo ao trabalho ou por mostrarem-se incapacitados por algum outro motivo ${ }^{15}$, devem prover carne para os membros de sua casa de outras formas. Comprar carne no mercado é algo corriqueiro tanto em Paygap como em Iterap. Boa parte da renda de uma família 16 é destinada para as compras realizadas na cidade de Ji-Paraná. Os itens fundamentais são arroz, feijão, açúcar, sal, óleo e sabão. A família de um homem que não caça despende parte de sua renda na compra de carne. Ainda assim, nenhuma pessoa suportaria alimentar-se exclusivamente de carne não silvestre. Os Arara são carnívoros contumazes e grandes apreciadores da gordura.

Todo caçador possui sua própria espingarda, cuidada com bastante zelo. É com ela que sai para caçar, quase sempre já com uma presa em vista. Os homens preferem caçar de noite, em noites que a lua demora a surgir no firmamento, para que não possam ser vistos pelas presas. Afora caçadas coletivas empreendidas em ocasiões rituais, como acontece antes ou durante a Festa do Jacaré e o Encontro de Pajés, os

\footnotetext{
15 Os assalariados das aldeias são aqueles que ocupam os cargos de Agente Indígena de Saúde (AIS), Agente Indígena Sanitário (AISAN) e professor(a). Há também aqueles que não têm condições físicas de caçar por apresentarem alguma doença crônica ou passageira.

${ }^{16}$ As principais fontes de renda de uma família são as atividades listadas na nota anterior e o Programa Bolsa Família. Também se obtém algum dinheiro com a venda de artesanato em palha, tucumã e algodão. Em Paygap, alguns homens prestam serviços a fazendeiros e assentados da região.
} 
homens saem para caçar sozinhos ou em duplas. Caçadores mais jovens também costumam sair em trios. A composição das duplas varia. Em Paygap, onde o mato - termo em português para naxo, que designa o ambiente da floresta - é mais próximo da aldeia e onde pude observar um trânsito maior de caçadores saindo e chegando, os homens costumam caçar sempre com o mesmo parceiro, a quem chamam de pagon. A palavra é em geral traduzida por "amigo" ou "companheiro", e refere-se a uma categoria geral de amizade, podendo ser usada em vários contextos de parceria. O companheiro de um caçador pode ser um cunhado, um tio materno ou o marido da mãe. Um pai também costuma caçar com seu filho quando ele ainda é jovem. Curiosamente, em poucas ocasiões vi irmãos saindo juntos para caçar. Parece-me que a relação por excelência que a atividade cinegética coloca em tela é a da amizade entre dois homens. A isso associa-se a forma de compartilhamento da presa. Um homem não deve jamais reter a cabeça, uma das partes mais nobres da caça, e o braço esquerdo de sua vítima. Esses pedaços são, via de regra, doados ao pagon dele. Mesmo quando o caçador sai desacompanhado, ao retornar para a aldeia, ele irá oferecer estas partes ao companheiro ou a algum parente.

Nunca obtive qualquer interpretação para esse costume que não se guiasse por enunciados "culturalistas". Estas partes são doadas "porque na nossa cultura é assim" ou "porque é o costume" eram invariavelmente as explicações fornecidas. Minhas tentativas de atribuir uma ação maléfica à ximit (alma) do animal caso o caçador viesse a reter essas porções também eram categoricamente rejeitadas. Os Arara insistem que os bichos que fazem parte da dieta alimentar não fazem mal. Isso, claro, até que o acontecimento prove o contrário, principalmente no período de couvade. Caso, por exemplo, um queixada (yate) venha a fazer mal para um recém-nascido, as pessoas prontamente atribuirão o adoecimento do bebê a uma ação impetrada pela ximit do animal. Afirmam que para o bebê o porco tem alma, mas não para um adulto que não se encontra em regime de couvade. Versados que são nestes assuntos, para os Arara a alma é sempre uma relação ou um ponto de vista (cf. LIMA, 2002).

Se pensarmos o costume arara de doar a cabeça e o braço esquerdo da presa em um quadro mais amplo de reflexão sobre caça, 
guerra e predação na Amazônia, podemos entendê-lo como uma ação que visa separar a parte agente do animal de sua parte comida, desprovendo-o da capacidade de agir, "capacidade que é própria aos seres em sua condição de pessoa" (FAUSTO, 2002, p. 16). Como coloca Carlos Fausto,

\begin{abstract}
se só consumissem animais-agentes terminariam por ou bem identificar-se com eles (tornando-se um deles), ou bem por não reconhecer outra forma de relação além da devoração. Eis por que alguns caçadores não comem sua própria presa, ou não a transportam, ou evitam certas partes como a cabeça. Eles querem continuar a ser humanos, provendo de carne suas esposas, filhos e afins (FAUSTO, 2002, p. 35).
\end{abstract}

Parece-me que, além disso, o que a cabeça e a braço esquerdo objetivam é o imperativo de circulação e divisão da caça. Diferentemente dos Cinta-Larga, para os quais, segundo Dal Poz, a caça possui um caráter individualista, entre os Arara a presa abatida deve circular entre o maior número de pessoas possível. Entre os Cinta-Larga (falantes de Tupi-Mondé), as caçadas são, em geral, solitárias. Porém, quando um homem convida outro para acompanhá-lo, os animais abatidos pertencerão àquele que convidou, o béxipó, "o que anda na frente" (DAL POZ, 1991, p. 136). O abatimento de alguns animais, contudo, exige a cooperação de vários caçadores. A caça ao queixada e o retalhamento da carne de uma anta tornam coletiva uma atividade individual. O mesmo se passa nas caçadas coletivas realizadas para as festas.

Os caçadores arara também podem caçar sozinhos, principalmente em saídas diurnas. Ainda assim, dificilmente irão reter todas as partes de uma caça para si e sua família. Por meio da distribuição de carne, pode-se vislumbrar as relações entre pessoas que habitam uma aldeia: aqueles com quem repartem uma presa são mais parentes do que aqueles com os quais não se divide. Um homem, ao retornar de uma caçada, entrega a presa a sua esposa, que irá tratá-la e mandar as crianças ou jovenzinhos entregarem os pedaços crus e já limpos para aqueles com quem costuma partilhar a carne. Há variações quanto à distribuição de acordo com o tamanho da presa. A cabeça, quando não é doada à esposa do companheiro do caçador, quase sempre é destinada aos sogros de uma mulher que reside 
virilocalmente. As mulheres dos irmãos do marido também costumam receber alguma parte de acordo com o tamanho da presa e da proximidade geográfica e afetiva.

Em Paygap, uma aldeia relativamente pequena, algumas caçadas rendem carne que pode ser dividida entre todas as casas. Em uma ocasião, pessoas oriundas de todas as famílias reuniram-se na casa de um experiente caçador para irem buscar duas antas abatidas por ele na noite anterior. Em Iterap, embora familiares que moram em outra seção residencial possam receber um pedaço de carne, a maior parte da caça costuma ficar dentro de uma mesma seção. É impensável que uma caçada possa alimentar toda a aldeia. Uma jovem mulher de Iterap explicou-me que não dividem a caça entre todos porque, diferentemente do que se passa em Paygap, são muitos. O pai dessa jovem traça uma relação entre parentesco, proximidade geográfica e compartilhamento da carne que expõe com precisão os modos de divisão da caça.

A caçada hoje em dia se tiver parente perto a gente divide. Por exemplo, se caçar um porcão que a gente faz cozido, moqueado, paçoca, divide só pra quem está pertinho de casa né! Às vezes, quando alguém vai passear na minha casa, nós temos esse costume ainda, eu não vou deixar ele sair sem provar a carne. Ele tem que provar a caça que eu matei. Se ele não for, eu não falo pra ele que tem, mas se ele for, a gente oferece (ARARA, Firmino Ot Xavã apud DE PAULA, 2008, p. 182).

Esta relação entre tamanho da presa e raio de distribuição dá a tônica do partimento da carne. Porém, o discurso nativo, especialmente aquele formulado pela família de Arõy e Pedro, dá notícias de que os produtos de uma caçada eram, em qualquer situação, divididos entre todo mundo tanto no tempo da maloca quanto assim que se reuniram após a dispersão nos seringais. Além do fato de que este todo mundo era menos gente, essa imagem da caça enquanto produto coletivo precisa ser melhor analisada. Ela é um modo de as pessoas falarem de transformações na socialidade que também podem ser ditas por meio do idioma do grau de fermentação da macaloba e de divisão das roças. 


\section{Pedaços de caça}

Além do crescimento populacional, outro elemento aparece nas falas de moradores de Paygap e Iterap como um perturbador das relações de reciprocidade estabelecidas por meio do compartilhamento e divisão da caça: os freezers e geladeiras que permitem reter ao invés de distribuir a carne. Demorei algum tempo para entender o que Arõy e Luiza, minhas principais anfitriãs em Paygap e Iterap, respectivamente, estavam a me dizer quando afirmavam que antigamente cozinhavam o bicho inteiro, péyup, e não em pedaços, xakû, como hoje. As duas mulheres contam que até pouco tempo atrás os animais eram preparados inteiros e só depois cortados em pedaços ou pisados no pilão. As pessoas cozinhavam todo o animal - e não retinham suas partes nos freezers como o fazem atualmente - e o consumiam entre todas as pessoas da aldeia, primeiramente os homens e, em seguida, as mulheres.

A isso associa-se a forma de preparo. Antigamente, eram destinados pedaços de carne já cozidos ou pisados às pessoas. Só quando o animal era repartido no próprio local do abatimento é que se recebia a caça crua. No presente, o mais ordinário é justamente distribuir pedaços de carne crua. Com exceção dos galináceos, é raro que as pessoas enviem carne cozida como uma oferta de caça.

Há uma percepção generalizada de que, no presente, ao contrário de outros tempos, as famílias preferem manter a caça entre os seus. Mesmo a cabeça e o braço esquerdo podem permanecer com o caçador caso ele tenha ido caçar sozinho. Uma forma de falar desta "transformação dos ânimos" é por meio da oposição inteiro/em pedaços. A distinção responde aos movimentos contrários de consumir entre "todos" ou de consumir aos poucos "entre si". Assim, uma caça grande, que, segundo contam, já foi um dia compartilhada entre um grande número de pessoas, atualmente pode ser guardada sob refrigeração para consumo familiar. Como coloca um professor em depoimento a De Paula:

mas a geladeira [...] acho que não é uma coisa muito boa. Às vezes a gente precisa... mata uma caça grande 
e guarda na geladeira... só que antigamente não precisava disso... a gente matava caça... fazia no moquém... deixava a carne passar muito tempo ali... não estragava. Antes dividia a caça... era melhor do que hoje... o povo era mais unido... as pessoas agora quase não é mais assim. Hoje quando mata uma caça... quase ninguém divide com a comunidade. Antes se você matava caça grande... dividia pra todo mundo... cozinhava inteirinho o porco... cozinhava mandioca... ou assava... fazia pamonha... e chamava todo mundo pra comer... pra participar do almoço. Agora... pessoal quando mata uma caça... guarda tudo aí (ARARA, Célio Nakyt apud De PAULA, 2008, p. 143-144).

O porco era cozido inteiro porque todos eram chamados para compartilhar a refeição. A comensalidade é um dos signos de um "povo mais unido". O todo - o porco inteiro - cabe a todos; as partes conservadas na geladeira do caçador - cabem às famílias. Praticamente todas as casas em que entrei nas duas aldeias têm uma geladeira ou um freezer.

À oposição pedaço/inteiro é associada uma distinção entre cru e cozido. Antigamente, quando a presa era preparada por inteiro, eram destinados pedaços de carne já cozidos ou pisados às pessoas. Somente quando o animal era repartido no próprio local do abatimento é que se recebia carne crua. No presente, quando se cozinham pedaços, o mais ordinário é justamente distribuir porções de carne crua. Pedaço, inteiro, cru e cozido aparecem enquanto quali-signos que produzem e compõem espaços-tempos valorizados de forma distinta por meus anfitriões.

No primeiro volume das Mitológicas, Lévi-Strauss anuncia o seu empreendimento de, por meio de uma análise dos mitos das Américas, "mostrar de que modo categorias empíricas, como as de cru e de cozido, de fresco e de podre, de molhado e de queimado etc. [...] podem servir como ferramentas conceituais para isolar noções abstratas e encadeá-las em proposições" (LÉVI-STRAUSS, 2004, p. 19). O que os mitos descortinam é um entendimento do mundo que se faz a partir de uma lógica do sensível. Desde este ponto de partida, o autor demonstra como a culinária é concebida pelo pensamento indígena como uma mediação. O que se pode vislumbrar nos mitos de aquisição do fogo doméstico é a passagem da natureza para a cultura por meio da 
transformação cultural do cru efetuada pelo cozimento dos alimentos e, particularmente, da caça. O fogo, ora roubado de um jaguar (como se dá em boa parte dos povos Jê), ora adquirido do urubu (como é o mais comum entre povos Tupi-Guarani), é um dos instrumentos de mediação possível dessa passagem, que, no primeiro caso, realiza-se a partir da oposição cru/cozido (o jaguar sendo o comedor de cru), e, no segundo, da oposição podre/cozido (o urubu enquanto comedor do podre).

Os Arara contam que as plantas comestíveis e o fogo foram trazidos do céu ou por tõyarõya, o pássaro chororó, ou por xiwât, bicode-brasa. Essas espécies atuam como mediadores entre o céu e a terra por meio do transporte do fogo, cujo dono era Toto Néw, a principal divindade do panteão arara17. No mito intitulado $A$ história do fogo, é bico-de-brasa quem traz uma brasa escondido da divindade. $\mathrm{Na}$ tradução, e não na transcrição ${ }^{18}$, as plantas são enumeradas: "foi ele que trouxe do céu, no bico, mudas de batata, milho, cará, mandioca, banana. Tudo o que ele achava lá, ele trazia para a terra e tudo que hoje se pode plantar, quem trouxe foi ele" (DILLENBURG, 2009, p. 34). A última frase do mito transcrito acima - "depois que acabou de trazer todas as coisas, aí ele pegou uma brasa e trouxe para nós" -, em conjunto com a enumeração das plantas contida na tradução, revela a relação do fogo com uma transformação que se dá, por um lado, no reino vegetal, e por outro, no reino animal. Apesar de sua brevidade, o mito do bico-de-brasa/chororó apresenta, ainda que um tanto quanto telegraficamente, todos os signos que competem à culinária arara: as plantas e os animais, que se tornam alimentos por intermédio do fogo. A socialidade arara funda-se justamente sobre o compartilhamento e troca desses alimentos.

Sem que a intenção seja tomar demasiadamente ao pé da letra os ensinamentos de Lévi-Stauss, parece extremamente significativo que

\footnotetext{
${ }^{17}$ Embora nunca tenha escutado os Arara dizerem que Toto Néw é ou já foi onça um dia, alhures apresento alguns elementos que apontam para uma afecção onça dessa divindade (OTERO DOS SANTOS, 2015 - ver capítulo 2).

${ }^{18} \mathrm{Na}$ maioria das histórias coletadas pela autora, transcrição e tradução não coincidem, as traduções sendo mais incrementadas e ricas em detalhes do que o material transcrito. Isso se deve muito possivelmente ao fato de os mitos coletados por Dillemburg, assessora do Comin (Conselho de Missão entre os Índios, braço da Igreja Luterana do Brasil que presta assessoria aos povos indígenas), serem muito curtos, algo que parece ser bastante comum na narrativa arara de mitos, a julgar pela extensão dos mitos coletados por diversos autores e por mim. Durante o processo de tradução, realizado com professores, informações devem ter sido acrescentadas e acabaram por compor a tradução do mito.
} 
minhas maiores interlocutoras, Arõy e Luiza, frisassem a mudança da oferta de carne cozida inteira para carne crua em pedaços como forma de falar das transformações da socialidade. É por meio de um vocabulário culinário que as pessoas se colocam na história. Assim, teríamos: inteiro + cozido : passado :: parte + cru : presente. Embora minhas amigas nunca tenham explicitado isso claramente, o ponto, conforme expresso na fala do professor transcrita acima, é que o tempo do (distribuído) cozido e do (cozinhado) inteiro é o tempo em que as pessoas comiam juntas. Trata-se, portanto, não de uma simples diferenciação das formas de preparo e distribuição da carne, mas sim de uma substituição da comensalidade pela repartição do alimento que não será comido junto. As pessoas oferecem porções cruas porque somente em raras ocasiões convidam-se outros que não os parentes próximos para comer.

No presente, cada mulher cozinha para seu marido e filhos. As pessoas se servem e comem sempre no interior de suas casas ou na cozinha, quando as têm separadas da casa, em família. O esperado é que um casal que já tem sua casa produza a comida para a sua subsistência. Ainda assim, mulheres que já possuem muitos netos, assumem uma posição diferenciada na rede de comensalidade e compartilhamento de alimentos. Pode-se dizer com segurança que quanto mais netos uma mulher tiver, mais ela irá trabalhar e contribuir para a nutrição daqueles que não moram com ela. Isso porque, embora toda jovem mãe deva cozinhar para a sua família, não é raro que os filhos dessas mulheres comam alguma coisa na casa de uma das avós, ou que ela pegue um pouco de feijão com a sogra para incrementar a refeição, ou, ainda, que seu marido coma na casa da mãe. Assim, embora as pessoas raramente comam juntas, as mulheres mais velhas estão sempre alimentando outros que não seu marido ou filhos e netos que moram com elas. Talvez pudéssemos definir um grupo doméstico a partir de uma mulher que alimenta outros que não os de sua casa.

\section{Bebida e roça, medidas das relações sociais}

As roças, naxey, geralmente pertencem a uma família nuclear e 
tanto o homem como a mulher que a cultivam são concebidos como seus donos. O homem é encarregado da derrubada e queima, feita na maioria dos casos com machado. Ele pode ser auxiliado pelos filhos, genros ou irmãos nesta atividade. Os adultos que já são sogros, contudo, reclamam que os jovens não querem mais trabalhar na roça e que acabam tendo que fazer a maior parte da derrubada sozinhos. As espécies mais cultivadas são macaxeira (manı), mandioca (maniók), cará (ya'mo ou mara'â), milho (nãya) e banana (iwa). Algumas poucas famílias plantam feijão e arroz. Outras frutas muito cultivadas são mamão e abacaxi. O algodão (mók) também está presente em quase todas as roças, sendo usado para a confecção de redes, tipoias, cocares e linha para colares e pulseiras.

No presente, as roças são exclusivamente familiares ${ }^{19}$. Alguns homens preferem trabalhar totalmente sozinhos, sem envolver os irmãos, o pai ou, o que é mais espantoso para os mais velhos, sem ajudar o sogro. Um grupo doméstico tem em geral roças contínuas. Homens de uma mesma seção residencial podem se ajudar mutuamente no trabalho de derrubada e roçado. No entanto, cada família nuclear (ou cada casa) planta e colhe livremente somente na área reservada para ela. Para colher os produtos de outra roça é preciso ser convidada ou pedir autorização para a sua dona. Este sistema gera algum descontentamento e reclamações. Cansei de escutar mulheres chateadas por terem seus produtos colhidos pelas parentas do marido ou por serem impedidas de colher suas plantas sob alegação de que determinada macaxeira ou cará não havia sido plantada por elas.

Parece haver algumas exceções a esse sistema. Ouvi falar de roças pertencentes a um grupo doméstico. Um homem de Iterap contou ter uma única roça com seus genros e filho, sendo os produtos de livre acesso para todos, por serem, segundo ele, "uma só família" e "quanto mais gente melhor, mais fartura".

Embora seja muito comum um homem plantar sua roça em um terreno aberto e trabalhado pelo pai, são muito malvistos aqueles que têm filhos e não dedicam parte de seu tempo ao cultivo das roças. Mais

\footnotetext{
${ }^{19}$ Com exceção da roça aberta em Paygap com recursos de um projeto do PDPI (Projetos Demonstrativos dos Povos Indígenas, do Ministério do Meio Ambiente). A roça, contudo, parece não ter sido bem cuidada e só presenciei a colheita de algodão por mulheres pertencentes ao grupo familiar de Arõy.
} 
escandaloso ainda são os recém-casados que não contribuem com os sogros. Sobre um adulto nem tão jovem que sequer tinha uma capoeira, escutei: "o pai dele que dá de comer". O mais estarrecedor e repetido duas vezes pela mulher que teceu o comentário era o fato de este homem sempre tomar macaloba na casa da sogra, expressando a posição do casal enquanto receptores e não produtores de alimento/bebida.

A maioria das roças fica longe das aldeias. Tanto em Iterap como em Paygap, onde algumas não chegam a ser tão longe, as pessoas atribuem a distância à presença do gado criado solto por alguns homens. Há sempre tentativas de cercar os bois ou as roças, o que costumam funcionar por um tempo. Entretanto, qualquer porteira aberta ou descuido com a manutenção das cercas e deslocamento do gado já é suficiente para os bois entrarem nas plantações alheias.

Os produtos oriundos da roça servem para produzir caldos, acompanhar a carne e servir como matéria-prima para iguarias como pamonha e bolos. Seu principal uso, contudo, é na fabricação da macaloba. A destruição das roças pelo gado ou outro bicho é lamentada primeiramente pela privação da bebida que ela acarreta. Outra preocupação esboçada pelos agricultores e agricultoras diante da ação dos animais é quanto à preservação das mudas. Quando se entristeciam com a perda de suas roças, estes eram os dois pontos enfatizados: a futura escassez de na'mẽk e a dificuldade de manterem as espécies, principalmente as variedades nativas. Se seguem investindo intensamente no trabalho agrícola mesmo com as incertezas provocadas pelo gado criado solto por alguns de seus donos, ou por animais do mato que ficam à vontade demais para se alimentarem de roças demasiadamente distantes, é porque sempre esperam tomar sua macalobinha na safra seguinte.

Como pode, então, um homem adulto, pai de quatro crianças, comer da roça de seu pai, não ajudar o sogro e ainda tomar macaloba daquela plantação com a qual não contribuiu? Seu lugar enquanto filho, pai e sogro é questionado por minha interlocutora. Na'mẽk e roça aparecem como a objetivação das relações entre parentes, ou melhor, da falha em constituí-las apropriadamente. Nos contextos de produção e consumo de bebida, caça e roça descritos até agora, fica evidente 
como a vida cotidiana sucede-se no seio da família. Por meio dessas coisas e dos atos que envolvem sua produção, circulação e consumo, as pessoas fabricam parentes, com maior ou menor grau de sucesso. Como produzir, então, uma espaço-tempo mais estendido, que não se restrinja ao código do parentesco, ou que seja capaz de produzir uma comunidade mais ampla de parentes?

Um sentimento de pertencimento a uma aldeia é algo um tanto quanto estranho aos Arara. Assim como se passa entre tantos povos Tupi-Guarani, "a parentela predomina sobre a aldeia" (VIVEIROS DE CASTRO, 1986, p. 179). A aldeia, portanto, não aparece, como costuma acontecer, por exemplo, entre os Jê, enquanto "uma unidade conceitual fundamental, seja como estrutura capaz de integrar os grupos domésticos, seja como fonte de identidade territorial" (VIVEIROS DE CASTRO, 1986, p. 179). Para os meus anfitriões, a vida desenrola-se no seio da família e do grupo doméstico; é este o "entre si" fundamental da socialidade cotidiana. Se a aldeia desaparece frente ao convívio familiar no dia a dia, isso não quer dizer que promover outros contextos de interação supra ou intrafamiliares não esteja no horizonte comum. As pessoas vivem e gostam de viver entre si. Elas, porém, também anseiam por, ou sentem falta de, uma vida entre outros.

Como vimos, a emergência de contextos mais amplos de sociabilidade se faz com enormes dificuldades, o que é lamentado por meus interlocutores, especialmente aqueles de Paygap. Na família de Pedro, a dicotomia junto/separado (ou junto/individual) é acionada para marcar uma diferença entre um passado no qual o desejo era de estarem juntos e animados e um presente no qual a maioria das pessoas prefere estar separado ou individual, ou seja, viver, trabalhar e entreterse em família. Este passado pode referir-se ao tempo da maloca, quando a associação mais conspícua é com o modo de habitação. $O$ mais usual, porém, é o junto referir-se ao período de reunião das pessoas após a dispersão pelos seringais da região, os signos da junção e alegria sendo não mais a casa, mas a caça, a roça e a festa ensejada pela bebida. Assim como se passa no processo de fabricação dos corpos de parentes, são essas coisas que produzem coletivos mais amplos em contextos rituais e, no passado recente, nas ocasiões de trabalho coletivo nas roças. Diferentemente da doçura envolvida na produção 
cotidiana do parentesco, estes contextos impõem o uso da bebida fermentada. Como veremos, é a embriaguez associada à alegria que possibilita(va) o surgimento de modalidades mais ampliadas de "entre si". As diferentes escalas de coletivização aparecem como função das relações sociais que se constituem de formas particulares e distintas por meio da circulação ou compartilhamento de bebida, trabalho envolvido na roça e caça. Esses ícones criam diferentes espaços-tempos. Se, nas seções anteriores, apresentamos o espaço-tempo do parentesco e da família, passaremos agora a uma discussão sobre a produção do agregado aldeão.

Quando abriram Iterap, fez questão de me dizer Arõy, "Pedro plantou muita macaxeira; deu muita macaxeira", o que anuncia muita macaloba, que significa muita animação e, por conseguinte, a possibilidade de estabelecer muitas relações. A época de fartura distingue-se do tempo presente, quando a maioria das pessoas diz não mais fabricar bebida fermentada "porque não tem mani", o que penso dizer menos sobre a produção das roças do que sobre certos desejos e engajamentos. A alegada diminuição da produção das plantações - seja devido à destruição dos roçados pelo gado, ao tempo despendido em trabalhos remunerados, que levam à negligência no cuidado com a roça, ou por preguiça (nos termos das pessoas) - não deixa de apontar para uma retração das relações supradomésticas. Embora insistam em dizer que "não tem macaxeira", essa afirmação tão frequente parece significar que o que não há é (tanta) macaxeira para alimentar pessoas que não sejam da família ou para proporcionar reuniões (embriagantes) em coletivos maiores.

No início, o lastro desta asserção parecia um tanto misterioso, uma vez que cansei de ver as mulheres retirarem os produtos de suas roças ou adentrarem a aldeia com seus paneiros abarrotados. De certa forma, ela concerne às espécies de forma diferenciada. Assim, a batatadoce, um ingrediente imprescindível para a produção de na'mẽk kap, é um dos produtos cuja escassez é mais lamentada. Em Paygap ela foi atacada por uma praga, deixando as famílias sem a planta, que passou a ser comprada nos mercados de Ji-Paraná. Em Iterap, algumas famílias ainda têm um pouco em suas roças. As pessoas também lamentam a perda de variedades de cará. A principal ausência, contudo, refere-se à 
macaxeira. A espécie é invariavelmente o referente mais acionado para falar da falta: "não tem mais mani" e, por isso, não tomam mais bebida fermentada 20 .

A redução da disponibilidade das matérias-primas para o preparo da bebida, todavia, não afeta a produção da macaloba $b o a^{21}$. Mais do que um problema de mudança cultural ou de produção agrícola, a indisponibilidade relativa desses produtos aponta, acredito, para uma mudança de desejos. A "escassez" de cultivares é o principal motivo alegado para o refreamento no consumo da bebida fermentada, que se dá usualmente entre outros que não os parentes próximos. Embora ninguém nunca tenha me dito isso claramente, desconfio que as reuniões embriagantes eram em torno de nãya kap (receita de milho) e marixá (a receita arara de bebida de macaxeira) ${ }^{22}$. As variedades de cará eram sempre consumidas em versão doce. Isso talvez explique a afirmação de Arõy sobre o cará ser cultivado em roças individuais e a macaxeira em roças coletivas, como mostro mais adiante.

Em meu primeiro ano em campo, à minha pergunta sobre o porquê de não tomarem mais macaloba azeda a resposta variava entre duas possíveis: porque "não tem macaxeira" (em Paygap e em Iterap, onde uma mesma pessoa poderia me dar as duas respostas em momentos distintos a depender do contexto) ou por causa da igreja (em Iterap). A conversão a uma linha da igreja batista data de aproximadamente 2008 e arregimenta, ainda que com diferentes graus de envolvimento, a maioria das famílias de Iterap. Do período em que estive na aldeia, somente alguns poucos homens não frequentavam nunca aos cultos, que acontecem nas noites dos fins de semana.

Os moradores de Iterap contam que já estavam parando de tomar bebida azeda quando o missionário e sua família foram acolhidos na aldeia, após serem expulsos da casa que ocupavam em área de um fazendeiro. As pessoas já não queriam mais beber por causa das confusões e desentendimentos que a embriaguez ora suscitava,

\footnotetext{
${ }^{20} \mathrm{Na}$ tese, tomei a queixa da falta de mani exclusivamente como símbolo dessa escassez generalizada, o que acredito não ser correto. Quando as pessoas afirmavam não ter mais macaxeira, elas estavam referindo-se de fato a essa espécie.

${ }^{21}$ Ao menos em Paygap, onde raramente as casas ficam sem a bebida. Na outra aldeia, era mais comum eu visitar residências que não dispunham de na'mẽk kap pe'wit.

${ }^{22}$ Vale observar que o nome do cauim yudjá produzido em grande quantidade e, por isso, capaz originar a cauinagem é maritya.
} 
"acharam melhor parar, dava muita briga". Os homens ficavam bêbados e começavam a se lembrar de acontecimentos passados, o que, no calor da bebedeira, suscitava brigas (especialmente entre os mais jovens) e, no dia seguinte, vergonha. Pelas falas que escutei sobre a questão, creio que meus interlocutores concordariam que uma decisão coletiva de cessar as práticas de bebida estava em curso quando se converteram. Poderíamos especular se essa decisão não teria inclusive contribuído para o acolhimento do casal. Afinal, os Arara sempre tiveram missionários em suas terras, porém, jamais haviam se convertido e até 2009 nunca tinham tido uma igreja.

Quanto à queixa nativa sobre a redução da disponibilidade dos cultígenos, creio que ela nos fala mais de uma transformação das relações sociais que são objeto de investimento pelos Arara do que propriamente do cômputo da produção agrícola. Refiro-me aqui ao que identifico como uma alteração na disposição de se proporcionar uma interação entre grupos domésticos distintos ou entre parentes mais distantes, enfim, de se estar em coletivos mais englobantes. Ou, mais precisamente, de estar ou fazer (certas coisas) juntos. A relação entre roça e bebida não deveria, portanto, ser interpretada nos termos de uma relação de causa e efeito unívoca. O que importa aqui é como a diferença entre escassez e fartura dos bens da roça opera na descrição nativa dos regimes de socialidade e constituição de coletivos. É dizendo que não se bebe mais tanto, nem juntos, que os Arara estão a falar, nos termos deles, de outro regime de socialidade, nos nossos termos.

Em geral uma figura taciturna e fechada, o cacique de Paygap gostava de contar como foi bonito quando o povo reuniu-se novamente após o período de dispersão pelos seringais: "todo mundo trabalhando junto, fazendo festa, todo mundo unido". É preciso dizer que Pedro retornou com a mãe para o convívio com os parentes justamente durante esse momento em que os Arara abriram os primeiros lugares após saírem do seringal da Penha. Sempre muito nostálgicas, as falas do cacique acerca desse momento sublinham o sentimento de união e alegria. As pessoas reencontraram-se e puderam retomar algumas atividades de forma coletiva, interrompidas ou enfraquecidas pelo engajamento na empresa seringalista. A beleza atribuída a este momento perpassa basicamente três esferas da vida social, a 
comensalidade, o trabalho e a festa, como se pode perceber no trecho a seguir:

Pedro: Porque de antigamente, o povo conta, tinha tudo, as mulher tá ali, onde tá com a macaxeira, outro lava, outro já bota no fogo, outra...

Júlia: Fazia junto?

Pedro: [...] já foi coando no pilão. Naquela época não tinha panela nem balde ainda. Todo mundo comia junto. Todo mundo trabalhava junto. Nada não tinha divisão com o índio não. Tudo que o índio fazia era junto. Se matasse um peixinho, era junto. Se matasse um bicho pequeno, todo mundo comia junto. Então era assim. Não tinha essa divisão que tem hoje. (Entrevista com Pedro Agamenon, Aldeia Paygap, 11 de setembro de 2012).

"Não tinha divisão com o índio não": a bebida, as roças e a caça faziam as pessoas reunirem-se, algo muito similar ao que conta Kara'yã Péw, professor em Iterap e um dos meus principais interlocutores:

antes a caça também era coletiva... o povo quando caçava... dividia pra todo mundo. Hoje... a maioria das pessoas... caçam individualmente... hoje uma família só já são várias pessoas e não dá pra dividir um porcão pra todas as pessoas da comunidade... que não é muito grande. Mas antes tudo era dividido... caça... bebida... e roça... quem fazia macaloba convidava o pessoal pra tomar de madrugada. Fazia uma sopa de madrugada (ARARA, Sebastião Kara'yã Péw apud DE PAULA, 2008, p. 173 , grifo meu).

Assim como se passa com a fabricação de parentes e do "entre si" familiar, a produção do agregado aldeão também depende da bebida, da caça e da roça, tomadas como da ordem da divisibilidade ou indivisibilidade, como veremos a seguir. Essas instanciações de um "entre si" mais ampliado materializado na unidade da aldeia, tão presentes nas memórias das pessoas, mostram-se rarefeitas no presente. As ocasiões não rituais em que se pode originar um wat tap (um grupo de parentes) que abarque todos os moradores do lugar desapareceram - caçadas, derrubadas de roça e "bebedeiras de fim de semana" - e o todo mundo rareou. 


\section{Pedaços de roça}

Uma oposição equivalente àquela aplicada na esfera da caça entre cozido inteiro e pedaços crus - aparece nas falas dos Arara quando comparam o sistema de produção agrícola ao longo do tempo. A distinção relevante se dá entre koti naxey, "uma roça"23 (ou, em português, "roça comunitária") e "roça individual" ou "familiar"24. No tempo da maloca, conforme concebido pelos que o pensam desde o presente, cada unidade residencial tinha uma grande roça que alimentava todos os seus moradores. A roça era comunitária, dizem as pessoas. Esta afirmação destoa do padrão de roças familiares amplamente predominante entre os povos ameríndios. Mantendo-se somente na vizinhança dos Arara e tomando como exemplo os Gavião e os Cinta-Larga, é certo que havia mais de uma roça por maloca. Segundo Dal Poz (1991, p. 137), entre os Cinta-Larga, cada homem casado deve ter uma roça. Aquela de maior extensão, contudo, é a do zápiway, o dono da maloca. Felzke (2007, p. 35) afirma que, antes do contato com o SPI, os Gavião jamais tinham feito roças coletivas. Mesmo as roças organizadas por famílias extensas não eram tão comuns, sendo os roçados cultivados por famílias nucleares o padrão.

De certa forma, todo começo envolve uma "roça comunitária", o que suponho dizer menos das roças comunitárias do que dos começos. Afinal, as aldeias costumam ser abertas por uma família que inicialmente possui uma roça, isto é, uma roça familiar; neste sentido, esta "uma roça" acaba dando origem a uma nova aldeia. A existência de mais de uma plantação é corroborada pelo depoimento de um homem em Isidoro: "não existia cacique, apenas JAT XU (sic), isto é, a pessoa que construía a maloca, que tinha a roça maior" (ISIDORO, 2006, p. 18). Com base na fala de professores indígenas, a autora afirma que, no tempo da maloca, "cada família tinha sua roça. Trabalhavam juntos, mais ou menos no sistema de mutirão. No período de derrubadas e

\footnotetext{
${ }^{23}$ Kotì, do numeral um (1), e naxey, roça.

${ }^{24}$ Desconheço o termo na língua arara para essas roças. Das vezes em que presenciei alguma discussão na língua sobre esse aspecto, em contextos em que os incitava a falar sobre o assunto, a forma de aludir a essa configuração da roça era por meio da imagem de um dono que doa uma parte. Ressalto que as conversas que travei com meus amigos eram em português.
} 
colheitas, celebravam com muita festa quando havia muita comida e na'mẽk kap" (ISIDORO, 2006, p. 18).

Esta afirmação condiz em parte com o que algumas mulheres mais velhas contam. Segundo elas, a roça ficava situada próxima à maloca, um grande diferencial em relação às plantações de hoje. Os homens derrubavam e roçavam juntos, porém, cada mulher tinha a sua própria parte onde plantava e colhia suas plantas. Os homens mais velhos, contudo, deram-me depoimentos divergentes sobre esse ponto, afirmando que era uma única e grande roça que alimentava todos os moradores da unidade residencial.

Decidir sobre a unidade ou pluralidade das roças não se apresenta como um caminho profícuo para a compreensão da questão. Parece-me antes ser necessário investigar o que uma roça objetifica. Ainda que alguns homens corroborem a versão feminina, possivelmente a diferença de perspectivas segundo o gênero é explicada pelo fato de os homens trabalharem juntos em uma terra que, somente depois de concluído o trabalho de queima e derrubada, vem a materializar claramente alguma divisão. As mulheres já empenhariam seus esforços produtivos sobre determinadas "áreas". As perspectivas feminina e masculina, todavia, equivalem-se, uma vez que, assim como os homens e mesmo admitindo em algumas situações a existência de áreas de colheitas familiares, as mulheres insistiam comigo que na maloca havia uma única e grande roça.

Essa insistência é apoiada nos mais diferentes argumentos, acionados segundo a formulação de minhas perguntas. Quando eu indagava se havia uma única roça na maloca, como me afirmaram assim que comecei a pesquisa, as pessoas respondiam que era uma grande roça, na qual todos trabalhavam juntos: os homens derrubavam, queimavam e roçavam juntos e as mulheres também empreendiam colheitas coletivas mesmo em ocasiões não rituais. Quando eu procurava saber se as mulheres podiam retirar os produtos de qualquer parte da roça, homens e mulheres enfatizavam que antigamente as mulheres convidavam umas as outras para irem à roça. Nas palavras de Arõy, "a mulher não saía sozinha para tirar macaxeira não. la tudo junto, a mulherada". Outra resposta possível era "a gente comia junto". A bebida fermentada também era produzida coletivamente por ma'pây 
tap, a mulherada. Luiza, afirmando ser permitido retirar as plantas de qualquer parte, acrescentou, o que talvez seja a chave para 0 entendimento: "todos eram parentes, ninguém sovinava".

Ora, só se pode demonstrar generosidade em relação àquilo que se possui, o que atesta alguma posse sobre as plantas. A saliência dos aspectos coletivos da roça associada a certo mascaramento de seu caráter individual (familiar) - sustentados ora pelo trabalho coletivo que ela aciona, ora pela comensalidade ou pela generosidade das possíveis donas - atestam algo que eu demorei muito tempo para compreender: a matemática da roça (uma ou várias?) parece não ser tão relevante para os meus interlocutores. Todas as vezes em que eu tentava estabelecer uma divisão ou separação da roça por família, as pessoas recusavam essa descrição em favor de uma caracterização que sustentasse uma imagem de coletivização, mesmo que isso solapasse a ideia de uma roça, como no caso em que as mulheres admitiam que as áreas da grande roça tinham donas. Suspeito que o importante de se reter da socialidade da maloca e mesmo do período inicial de realdemento é aquilo em que ela se diferencia do presente: um pendor para o junto e o coletivo: "todos eram parentes, ninguém sovinava".

No tempo em que viveram no Posto Central, a primeira aldeia que juntou as famílias reunidas pelo SPI, os Arara tiveram roça comunitária ou coletiva. Após o momento inicial de reunião, as pessoas voltaram a trabalhar em suas colocações de seringa, permanecendo mais tempo por lá do que na aldeia. Cada família tinha sua rocinha no terreiro de sua colocação e também trabalhava na roça do posto, fazendo a derrubada, roçando e plantando. Realizado esse trabalho retornavam para seus locais de extração de seringa. Quando os alimentos estavam prontos para serem colhidos, deslocavam-se para o posto para usufruir dos alimentos e reunir-se. Tomavam bebida fermentada e faziam, no dizer dos meus amigos, brincadeira, referência à dança ensejada pela bebida.

Assim que as famílias estabeleceram-se em Iterap, também fizeram uma roça comunitária, onde plantaram arroz, cará, mandioca e banana. A casa de farinha instalada no lugar servia cada vez a uma família, que passava cerca de uma semana no local, produzindo a farinha para o próprio consumo, estabelecendo, portanto, um uso 
familiar de um bem comum. Em pouco tempo, contudo, as famílias desistiram de se engajar nas roças coletivas e voltaram seus esforços para roças individuais. Dois motivos são listados para explicar essa escolha: i) algumas pessoas que passavam mais tempo na cidade do que na aldeia queriam colher, sem autorização dos produtores, os produtos de uma roça na qual não trabalharam; ii) uma única família assentou-se próximo à roça, apossando-se dela. Com este desgaste, os bichos de casa e do mato foram comendo o roçado. $\mathrm{O}$ abandono da roça em favor dos bichos parece apontar para alguma confusão quanto a quem pertencia essa roça. Uma roça sem dono, só pode ser "apropriada" pelos animais.

No Posto Central e em Iterap, a roça comunitária sempre conviveu com as roças familiares, ambas fruto do trabalho coletivo, como a fala de uma professora de Iterap nos faz entrever:

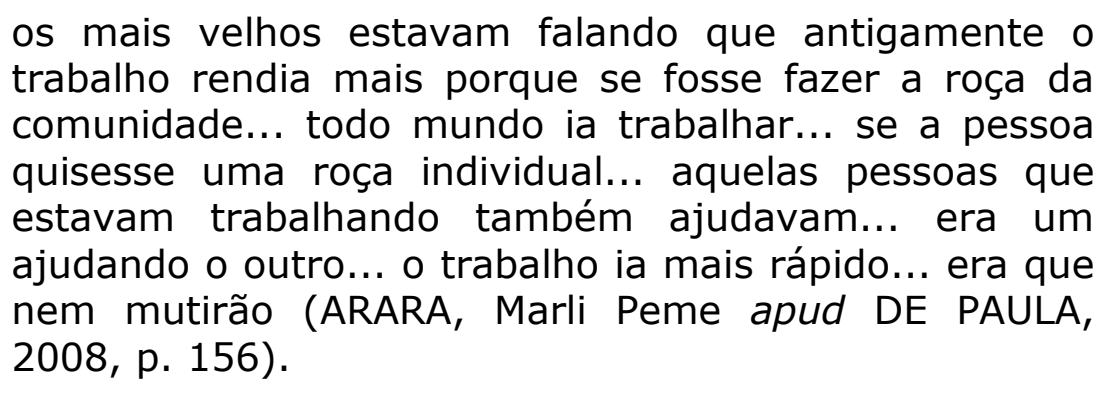

No pensamento nativo, a roça comunitária e o mutirão aparecem como práticas análogas pelo trabalho coletivo que engajam, isto é, por colocarem sob responsabilidade de um coletivo maior - no tempo da maloca, de todo o grupo doméstico; no período inicial do realdeamento, de toda a aldeia - atividades que poderiam ser realizadas no seio da família conjugal ou do grupo doméstico. Neste sentido, ambos opõemse aos roçados familiares que são abertos atualmente, uma vez que estes não são capazes de mobilizar pessoas provenientes de diferentes grupos domésticos. O arranjo mais comum é um pai e seus filhos abrirem juntos uma roça sem contar com o apoio dos demais homens da aldeia. Cada mulher terá, então, a sua própria parte nesta plantação contígua.

Podemos nos perguntar se o cultivo de grandes roças comunitárias não estaria relacionado a um novo arranjo em aldeia. Leonel (1983) relata os desmandos do chefe de Posto do Lourdes, que 
obrigava os Gavião a trabalharem seis dias por semana, remunerandoos com comida e com promessas de uma grande colheita nos anos de 1980 e 1981. As dificuldades de transporte na época da chuva acabaram impossibilitando o escoamento da produção para venda. Ainda que essa tenha sido a realidade em muitos postos indígenas no Brasil, desconfio que a ideia de uma roça coletiva não é totalmente estranha aos Arara. Ela, contudo, provavelmente restringia-se ao cultivo de macaxeira para a produção de marixa. Um trecho de conversa com Arõy é elucidativo nesse sentido:

Aróy: Cada uma... Toda a vida eles andava com as coisas assim. Plantava junto. Eles plantava macaxeira, aí todo mundo ia lá pegar.

Júlia: Podia tirar de qualquer lugar...

A: Podia tirar.

J: ...ou cada um tinha seu lugar pra tirar?

A: Cada um tinha, eu acho. Tinha não, eu acho. Era assim. Fazia roçado grande. Aí todo mundo plantava. Outras coisas que ele plantava cará separado. Cada qual tinha cará dele.

J: Seu cará?

A: Ahã.

P: As coisas que eles carregavam separado era só isso.

J: Cará plantava separado, mandioca plantava junto?

A: Junto.

É neste sentido que podemos compreender a queixa quanto à privação de macaxeira. Ela é um dos ícones de um espaço-tempo do junto. Assim como parece ser o amendoim para os Panará - uma planta "altamente valorizad[a], não como alimento em sentido nutricional, mas como um indicador crítico do viver bem" (EWART, 2005, p. 23). O cultivo e colheita dessa variedade envolvem todas as famílias, uma vez que "a cada ano, os amendoins de todos as roças são literalmente disseminados por toda a aldeia, uma vez que o cultivo de amendoim de cada casa é composto de pequenas partes das roças de todos os demais" (EWART, 2005, p. 25). Não tenho dados que possibilitem reconstruir o modelo arara de plantio da macaxeira, porém, parece-me certo que, assim como se passa com o amendoim entre os Panará, ele exigia um disponibilidade subjetiva de abertura ao outro, um estado de animação, como veremos mais adiante.

A desarticulação das práticas coletivas é sentida muito 
profundamente principalmente por aqueles que chegaram a viver o tempo da reunião após o período no seringal. Diferentemente da união e alegria proporcionadas pelo engajamento dos coaldeãos nos mutirões ou nas roças comunitárias, atualmente os Arara deparam-se com desentendimentos e tensões em torno das roças. A ação devastadora do gado nas plantações alheias já ocasionou o assassínio de boi do vizinho e até ameaças de morte. A restrição imposta pela opção de se sedentarizarem também gera disputas por antigas capoeiras e uma aproximação cada vez maior entre roças de diferentes famílias. Uma senhora que reclamou do avanço das roças do vizinho, com quem mantém um parentesco distante, lamentou comigo: "esse povo é assim mesmo. Não tem como afastar eles. Cada vez mais chega perto do outro".

Esse desejo de estar separado e de criar afastamentos claros entre as famílias é o movimento contrário ao da valorização do junto conforme aparece sob a forma de kotì naxey (uma roça) ou xim peyup (carne inteira), estes ícones responsáveis pela criação de espaçostempos estendidos. A vida arara é, no presente, feita predominantemente de cortes, separações. Pedaços de roça, pedaços de caça, espaços-tempos contraídos.

\section{Alegria, morte e embriaguez}

As pessoas fazem coisas juntas, como bebida, roça e festa, porque encontram-se animadas. Um mesmo estado psicofísico é condição para o engajamento coletivo nessas práticas: wãw nãn, uma expressão traduzida como "estar animado", equivalente ao estado de "alegria", conforme aparece na literatura americanista. Ao contrário das crianças, que vivem contentes à toa, ou de alguns pássaros, que, ainda que solitários, são alegres porque cantam, para adultos, o estado wãw nãn é eminentemente sociável e imprescindível para a criação da sociabilidade; exibido nos corpos por meio da disponibilidade ao outro e do embelezamento corporal25, ele é um qualisigno positivo, que

\footnotetext{
${ }^{25}$ A ornamentação do corpo, por meio da pintura de jenipapo e urucum, do uso de vestimentas de palha de tucumã e de colares de tucumã, dá-se em contextos rituais, sendo menos usual no cotidiano.
} 
objetifica a extensão do espaço-tempo intersubjetivo.

Certamente, o wâw nãn arara nos fala do que Ewart descreveu para os Panará como uma disponibilidade intersubjetiva presente na condição física e moral de suakiin, entendida pela autora como um estado "disposto" e "sociável". Aqueles que não estão alegres não conversam, preferem ficar sozinhos, quase não saem de casa, e não se enfeitam. Há, portanto, uma indisponibilidade de se abrir aos outros, um estado preguiçoso ou insociável, conforme Ewart (2005, p. 14).

Uma roça que coloca em movimento o trabalho de pessoas de diferentes grupos domésticos expressa, além da animação, o cuidado mútuo e o carinho que as pessoas nutrem umas pelas outras. É neste sentido, creio, que devemos entender o comentário de uma mulher acerca dos motivos que levaram as pessoas a optarem por roças individuais: "hoje ninguém gosta mais da gente". A dificuldade de trabalharem coletivamente é interpretada como uma ausência de afetividade, isto é, como certo ensimesmamento que impede que as pessoas/famílias se abram umas às outras.

No nível da pessoa, tal estado é perceptível pela introspecção, cansaço e desânimo que acomete um sujeito. A pessoa permanece em casa e, em boa parte do tempo, deitada em sua rede. Estar apaixonado ou enlutado são as principais causas para que uma pessoa encontre-se makôn, "triste". Ambas as condições designam o pensamento fixo em alguém ou alguma coisa, oxaro pay, estar com o coração/estômago morto [ $1^{\text {a }} \mathrm{P}$. O estado makôn pode ser compreendido como um qualisigno negativo: os corpos que o exibem mostram-se retraídos e fechados à expansão intersubjetiva, constituindo um espaço-tempo contraído e voltado para si mesmo.

Quando as pessoas não se mostram wãw nãn, as relações intersubjetivas contraem-se, impossibilitando a formação de um espaço-tempo mais ampliado. A forma primordial de ensejar alegrias é certamente a ingestão de bebida fermentada. O tempo de uma roça e dos mutirões, quando estavam juntos e unidos, é também o tempo da na'mẽk kap xa'yõk, a bebida em versão azeda, quando "todo mundo era animado". O que a bebida proporciona é que todos, isto é, gente suficiente, atinja o estado de wãw nãn, o que se mostra especialmente verdadeiro para o ritual. 
O consumo da bebida fermentada está intimamente relacionado às visitas, ao trabalho coletivo e às festas, isto é, a contextos que envolvem tap páy, "parentes outros". No período de realização da pesquisa, o uso restringiu-se a uma edição do Encontro de Pajés e outra edição da Festa do Jacaré, ambas realizadas em Paygap. Sobre a sua ingestão no passado, as pessoas sempre disseram não se tratar de um uso descontrolado, como percebem a relação do branco com sua pinga ${ }^{26}$, e também deles mesmos com essa bebida e a na'mẽk em um passado recente. Possivelmente influenciada pelas leituras sobre a imoderação das cauinagens alhures, demorei um bom tempo para entender que o grau de fermentação da bebida arara é relativamente baixo e que, mesmo em ocasiões rituais, o uso desmesurado da macaloba não é o que as pessoas sublinham. $O$ que as pessoas sempre enfatizam em relação à bebida azeda é o estado wãw nãn que ela aflora. As pessoas bebem para atingir uma condição de embriaguez associada à alegria, como a fala de Pedro deixa entrever:

Júlia: E tomava sempre macaloba azeda nessas festas? Pedro: Tudo, tudo. As vezes era pouco, não era muito, mas era bom também. Tinha um pouco pra animar, pra não cansar muito. Aí tem que ter um pouco, mas não assim pra cair pra não brincar. Festa você tem que tá animado, não beber pra cair. [...] Bebia, mas trabalhava do mesmo jeito. Então passava o dia todo trabalhando. Ninguém passava. Aqui mesmo já aconteceu depois que eu cheguei aqui já aconteceu muito isso. Ia todo mundo pra roça, trabalhava o dia todo, no lugar da água era a macaloba. Então o final de semana assim eles faziam festa mesmo, dois, três dias (Entrevista com Pedro Agamenon, Aldeia Paygap, $11 \mathrm{de}$ setembro de 2012).

Em alguma medida, as falas em torno de um uso controlado da bebida podem estar relacionadas à conversão dos moradores de Iterap. Porém, sua abrangência, em conjunto com outros fatores que destrincho a seguir, me fazem suspeitar que elas condenam, na verdade, um uso exagerado - menos em virtude da quantidade ou frequência do que das relações entre bebedores - que se fez em Iterap

\footnotetext{
${ }^{26} \mathrm{O}$ consumo de bebida alcóolica é raro nas duas aldeias, mas parece já ter sido mais intenso no seringal e em Iterap.
} 
antes de as pessoas abandonarem o seu consumo. As pessoas contam que, no tempo da maloca, quando havia festa em outra aldeia, os anfitriões preparavam a macaloba para os visitantes que chegavam à noite cantando e brincando. Quando quis saber se as pessoas visitavam outras malocas, um senhor respondeu-me: na'mẽk kap 'oa, para "tomar macaloba", o que foi prontamente traduzido por seu neto como "nas festas". Essas visitas regadas à bebida aconteceram até bem pouco tempo, quando as famílias se encontravam espalhadas. Elas costumavam colocar em contato diferentes grupos domésticos.

Sobre o uso da macaloba azeda depois que passaram a se estabelecer em aldeias, um professor explicou que "não tomavam todo dia, só quando tinha alguma coisa", isto é, em ocasiões de visitas entre parentes que moravam distantes, festas, mutirões na roça ou em qualquer empreitada que envolvesse o trabalho coletivo: "todo serviço tinha macaloba". Nos mutirões para a derrubada e roçado das plantações, a mulherada levava a na'mẽk para os trabalhadores terem força e ânimo: "era tomando macaloba e no machado". Mais recentemente, também tomavam nos aniversários. Quando algum homem desejava também podia encomendar a sua esposa a bebida para tomar no "fim de semana". O professor, que presenciou esses encontros somente quando criança, sente saudades desse tempo: "era bonito mesmo, pessoal era animado".

O que atrai as pessoas para a festa e o trabalho é a bebida fermentada. Na'mẽk kap xa'yók esquenta o corpo e o sangue; ela é o combustível para a dança no ritual, e para o trabalho nos mutirões. Gow mostra como entre os Piro, a circulação da cerveja de mandioca engendra justamente duas formas de socialidade:

uma é a festa de trabalho coletivo para a limpeza das roças e a construção de casa, a outra é a bebedeira. Ambas são essenciais para o casamento: a primeira no conjunto de trocas que consiste o casamento e a segunda em reunir jovens homens e mulheres enquanto amantes (GOW, 1989, p. 576).

A bebida impede que as pessoas se cansem e, o mais relevante do ponto de vista dos Arara, produz um sentimento de contentamento. A embriaguez e a alegria que ela dispara, nos ensina Lima sobre os Yudjá, 
retira as pessoas da intimidade da vida familiar, misturando-as em meio às outras (LIMA, 2005, p. 116). Essa combinação possibilita que a vida entre si abra-se à vida entre outros, proporcionando uma ampliação do espaço-tempo intersubjetivo, valorizado pelos Arara por sua beleza e alegria.

Se a bebida doce aparece como uma objetificação do parentesco ela fala das relações entre membros de uma casa ou de um grupo de casas e das relações de cuidado das mães com sua prole -, a versão fermentada é a objetificação da alteridade. Deste modo, a na'mẽk kap xa'yók é usada quando as pessoas encontram-se em meio àqueles considerados não parentes ou parentes distantes, com os quais não se costuma estar na vida cotidiana. A embriaguez provoca um abrir-se ao Outro, ou mais precisamente, um devir-Outro. A bebida fermentada coloca em tela uma espécie de "alteridade ao quadrado": uma relação com outros humanos (a interação entre grupos domésticos, entre aldeias ou entre povos), mas também uma relação com outros não humanos (o encontro entre vivos e mortos ou entre humanos e animais, como no caso da Festa do Jacaré).

Embriagar-se, em língua arara, é xahmòri, que em uma construção causativa, também significa enfeitiçar. A pergunta nãn emaxahmòri, "quem fez você ficar bêbado?", também pode ser traduzida como "quem te enfeitiçou?". A embriaguez é, portanto, um feitiço, uma tentativa de aniquilar o outro. A existência de uma correlação entre embriaguez e morte é uma das principais conclusões a que chega Lima em sua etnografia das cauinagens yudjá. Entre outros paralelos que a autora traça entre os dois estados, ela afirma que "a embriaguez de cauim é principalmente uma morte dos homens provocada pelas mulheres" (LIMA, 2005, p. 255). Uma narrativa do xamã Cícero revela como antigamente os mortos também apareciam para tomar bebida fermentada.

\footnotetext{
'Oraxexe

Quando a alma entrava em casa, os nossos parentes queimavam ela mesmo. Quando também tomavam macaloba, eles pensavam que a alma era gente quando ela vinha.

Dizem que ela falava, a alma: "Me dá macaloba".

Então o marido da mulher pensava que ela (a mulher
} 
dele) levava macaloba para a pessoa mesmo.

Dizem que ele (o marido da mulher) perguntou:

'Para quem você tanto leva macaloba?'

A gente tomava macaloba fazendo barulho 'xururu, xururu', mastigando a macaloba ralada [marixa kap], também na macaloba de milho verde [nãya kap].

$[\ldots]$

Quando eles (os antigos) dançavam, elas (as almas) também vinham se passar pelas pessoas, os nossos ancestrais contam para a gente.

Costumava dizer ela (minha mãe) para nós: "vocês vão pensar que são pessoas", dizia a minha mãe mesmo, antigamente.

Quando elas vierem (as almas) elas vêm enganando a gente.

Dizem que elas vinham, só tomavam macaloba, e iam embora.

(GABAS JR. e ARARA, 2009, p. 53-8).

O termo indígena glosado aqui como alma é 'oraxexe, o espectro do morto. O vocábulo para macaloba é na'mẽk kap, exceto onde indico o uso de marixa, a bebida feita com a macaxeira ralada, e de nãya kap, caso em que se está especificando que a bebida é de milho. A afirmação de que viam a alma como gente talvez sugira que aqueles embriagados pelo marixa ou na'mẽk kap estejam em algum grau também mortos. Pois enxergar o mundo desde o ponto de vista do outro é sinal de que já se é outro, conforme as célebres formulações de Lima (1996) e Viveiros de Castro (1986). E é a embriaguez a responsável por essa torção perspectiva. Beber macaloba azeda talvez seja chamar a morte, ser enfeitiçado, algo que a maioria dos Arara não parece estar mais disposta a fazer. Há evidentemente uma influência da igreja nessa decisão. Creio, contudo, que outro fator, de difícil formulação para meus anfitriões, também contribui para essa deliberação: desde que se fixaram em aldeias por um período mais longo, isto é, em Iterap e depois em Paygap, as famílias andam demasiadamente juntas.

Explico-me. Segundo Arõy, assim que se estabeleceram no igarapé Alquideia após o período em que viveram no seringal, todo mundo fazia macaloba quando o milho estava verde, e, então, "o pessoal ia espantar os que moravam mais longe". Espantar os outros é uma expressão usada para dizer que chegavam sorrateiramente nas casas visitadas para assustar os moradores, produzindo uma algazarra 
ao mesmo tempo alegre e assustadora. Para se tomar bebida fermentada é imprescindível uma distância, como a fala de Arõy nos faz suspeitar. Uma professora de Iterap é mais categórica. Quando conversávamos sobre as festas de antigamente, explicou-me o que os velhos já tinham me contado de uma forma mais sutil ("morava longe para poder passear na casa do outro").

Júlia: E quando fazia Festa do Jacaré vinha gente de várias malocas?

Cícero: Verdade. Maloca tudo.

Peme: Por isso que fazia maloca um distante do outro. Apây Maria não disse também que nem ele tá falando aí? Não era muito perto não. Pra ir passear na casa do outro. Que nem no Pedro. Quando tem festa ou mata caça (Entrevista com Cícero, Aldeia Iterap, 22 de outubro de 2012. Tradução de Sebastião Kara'yã Péw).

A percepção dos velhos que moraram em malocas e daqueles que viveram no esquema de colocações familiares após o período nos seringais é a de que as pessoas andam demasiadamente próximas. Como ouvi de um senhor de Iterap, os parentes da maloca "não moravam assim junto; hoje em dia nós moramos aqui junto". A fala da mulher que se ressente com a aproximação da roça do vizinho em direção à sua - "esse povo é assim mesmo; não tem como afastar eles. Cada vez mais chega perto do outro" - deve ser compreendida no mesmo sentido, o de uma proximidade excessiva.

É preciso, então, criar mecanismos alternativos de afastamento. Em Iterap, o distanciamento é produzido espacialmente na distribuição distanciada das seções residenciais umas das outras. As famílias costumam passar temporadas em seus sítios, como se referem a estas roças mais afastadas. Também está em curso um movimento de esvaziamento de Iterap $1^{27}$ desde 2002. Como dizem os meus amigos, estão aumentando de novo e, por isso, se espalhando. A julgar pelas divergências e pelas inúmeras acusações que escutei de famílias assentando-se em lugares que eram roças de outrem, a eficácia desse distanciamento é parcial.

Em um contexto de intensa mistura e proximidade, os moradores

\footnotetext{
${ }^{27}$ Nome dado ao núcleo original da aldeia, onde se concentram os serviços como posto de saúde e escola e se misturam diferentes famílias.
} 
de Iterap parecem ter experimentado duas alternativas quanto ao uso da macaloba azeda: seguir bebendo até o limite com parentes próximos ou uma abstinência completa. Contam que antes de pararem, estavam bebendo muito, o que gerava muita confusão. As brigas são elencadas como o principal fator para não desejarem mais beber. A raiva do bêbado, muitas vezes um afeto sem direção, gerava confusões e desentendimentos dos quais os Arara, principalmente as mulheres, mostram-se contentes por terem se livrado.

Em Paygap, embora as famílias encontrem-se todas muito próximas umas das outras, o movimento de afastamento também prevalece. Quando Pedro abriu o lugar, por volta de 1992, as casas foram sendo levantadas umas ao lado das outras em frente ao igarapé Prainha. Desde então, seu sogro, cunhados e posteriormente filhos moveram-se para lugares mais afastados. Mesmo que a distância entre as casas e famílias seja menor quando comparada ao esquema de núcleos residenciais que vigora em Iterap, ainda assim ela é produzida. Esse movimento é contínuo e faz parte do processo de produção de pessoas. Uma roça só é a pré-história e o futuro de uma aldeia devido à fabricação do parentesco que se desenrola no tempo. Um casal cujos filhos começam a se casar tendem a abrir seu próprio lugar. Todavia, a fixação em aldeias, algo pouco problematizado pelas etnografias das terras baixas, perturba a dialética permanente entre o junto e $o$ separado. Ao optarem por permanecer próximos à escola e ao posto de saúde, bem como à cidade de Ji-Paraná, as famílias encontram dificuldades para manter a distância necessária ao engajamento em práticas que possibilitam a constituição do espaço-tempo do junto.

A isso vincula-se também uma problemática fundamental para compreendermos o domínio do junto, que infelizmente não tenho como abordar nesse espaço: a política que se sucede na arena interétnica. Pois, além do aldeamento, outra novidade surge do contato com os brancos: a conformação de uma forma inteiramente totalizante do junto, a forma povo. Fazer essa forma aparecer para os brancos, para os vizinhos Gavião e para os próprios Arara é trabalho do ritual, único contexto no qual as pessoas ainda se dispõem a tomar bebida fermentada. Na maior parte do tempo, meus anfitriões preferem estar em um espaço-tempo marcado pela doçura e intimidade, ao invés de se 
lançarem à experiência da embriaguez e da alegria. Ao longo desse texto, busquei mostrar como as diferentes instanciações da bebida, da caça e da roça são a forma privilegiada (porque arara) para se ter acesso à compreensão arara de sua socialidade, esta marcada por uma dialética entre o junto e o separado.

\section{Referências bibliográficas}

DAL POZ, João. No país dos Cinta-Larga: uma etnografia do ritual. 1991. 394 f. Dissertação (Mestrado em Antropologia Social) - PPGAS, USP, São Paulo, [1991].

DE PAULA, Jania Maria. Karo e Ikólóéhj: escolas e seus modos de vida. 2008. 223 f. Dissertação (Mestrado em Geografia) - PPGE, UNIR, Porto Velho, [2008].

DILLEMBURG, Scheilla. Tap pãy tap at kanã xet: mitos arara. Ji-Paraná: Comin, 2009.

EWART, Elizabeth. Fazendo pessoas e fazendo roças entre os Panará do Brasil Central. Revista de Antropologia, São Paulo, v. 48, n. 1, p. 9-35, 2005.

FAUSTO, Carlos. Banquete de gente: comensalidade e canibalismo na Amazônia. Mana, Rio de Janeiro, v. 8, n. 2, p. 7-44, 2002.

FELZKE, Lediane. Quando os ouriços começam a cair: a coleta de castanha entre os Gavião de Rondônia. 2007. 111 f. Dissertação (Mestrado em Desenvolvimento Regional e Meio Ambiente) - PPGH, UNIR, Porto Velho, [2007].

GABAS JR., Nilson. A gramar of Karo, Tupí (Brazil). 1999. 297 f. Tese (Doutorado de Filosofia em Linguística) - University of California, Santa Barbara, [1999].

GABAS JR., Nilson; ARARA, Sebastião (Org.). Mitos Arara. Belém: Museu Paraense Emílio Goeldi, 2009.

GOW, Peter. The Perverse Child: Desire in a Native Amazonian Subsistence Economy. Man, Londres, v. 24, n. 4, p. 567-82, 1989.

HENARE, Amiria; HOLBRAAD, Martin; WASTELL, Sari. Introduction: Thinking through things. In: Thinking Through Things: Theorising Artefacts Ethnographically. London: Routledge, 2007. p. 1-31.

HOWARD, Catherine. PAWANA: a farsa dos "visitantes" entre os Waiwai da Amazônia setentrional. In: VIVEIROS DE CASTRRO, Eduardo Batalha; CARNEIRO DA CUNHA, Manuela (Org.). Amazônia: etnologia e história e indígena. São Paulo: NHII/USP/FAPESP, 1993. p. 229-64. 
ISIDORO, Edinéia Aparecida. Situação sociolinguística do povo arara: uma história de luta e resistência. 2006. 130 f. Dissertação (Mestrado em Linguística) - UFG, Goiânia, [2006].

LEONEL JR., Mauro de Mello. Relatório de Avaliação da Situação dos Gavião (Digüt) - P.I. Lourdes. Ministério do Interior e Fundação Instituto de Pesquisas Econômicas (FIPE), 1993.

LÉVI-STRAUSS, Claude. O cru e o cozido. São Paulo: Cosac \& Naify, 2004 [1964].

LIMA, Tânia Stolze. O dois e seu múltiplo: reflexões sobre o perspectivismo em uma cosmologia tupi. Mana, Rio de Janeiro, v. 2, n. 2, p. 21-47, 1996.

O que é um corpo? Religião e Sociedade, Rio de Janeiro, v. 22, p. 9-19, 2002.

- Um peixe olhou para mim: o povo Yudjá e a perspectiva. São Paulo: UNESP/ISA/NUTI-MN-UFRJ, 2005.

MUNN, Nancy. The fame of Gawa: a symbolic study of value transformation in a Massim (Papua Néw Guinea) society. Durham/Londres: Duke University Press Books, 1992 [1986].

OTERO DOS SANTOS, Júlia. Sobre mulheres brabas, parentes inconstantes e a vida entre outros: a Festa do Jacaré entre os Arara de Rondônia. 2015. 338 f. Tese (Doutorado em Antropologia Social) - PPGAS, UnB, Brasília [2015].

VIEGAS, Susana de Matos. Eating with your favourite mother: time and sociality in a Brazilian Amerindian community. Journal of the Royal Anthropological Institute, Londres, v. 9, n. 1, p. 21-37, 2003.

VIVEIROS DE CASTRO, Eduardo. Araweté, os deuses canibais. Rio de Janeiro: Jorge Zahar, ANPOCS, 1986.

Perspectivismo e multinaturalismo na América indígena. In: VIVEIROS DE CASTRO, Eduardo. A inconstância da alma selvagem. São Paulo: Cosac \& Naif, 2002. p. 345-399.

WAGNER, Roy. The Invention of Culture. Chicago: The University of Chicago Press, 1981 [1975].

Recebido em: 23/04/2016 * Aprovado em: 28/06/2016 * Publicado em: 31/12/2016 